\title{
19
}

\section{Subsistence and island landscape transformations: Investigating monumental earthworks in Ngaraard State, Republic of Palau, Micronesia}

\author{
Sarah Phear \\ Historic Environment and Archaeology Service, Worcestershire County Council, Worcestershire, UK \\ sphear@worcestershire.gov.uk
}

\section{Introduction}

Monumental earthworks in Pacific islands have always attracted attention, from ethnographers visiting the islands in the 19th and 20th centuries (e.g. Krämer 1917), through to archaeologists in the modern day (e.g. Osborne 1966; Parry 1984; Liston 1999). The earthworks of the Republic of Palau, Micronesia, have not escaped attention. When asked by Andrew Cheyne (1864) in the 19th century, local Palauan people attributed the terraces to work of the gods, or the actions of the sea during the great flood (Parmentier 1987:30). These landscape features have been the focus of several archaeological investigations over the past five decades (Osborne 1966, 1979; Lucking 1984; Masse et al. 1984; Liston 1999; Liston and Tuggle 2001). As such, they have undergone scrutiny by application of a range of theoretical and methodological approaches, each generally a product of its time, and resulting in often similar, although at times conflicting, interpretations. A critical analysis of these approaches can be found elsewhere (Phear 2007), and a brief summary suffices here.

A popular explanation for earthwork/terrace construction focuses on subsistence-related activities, but no direct evidence has been recovered to support this. When Osborne (1966, 1979) undertook his investigation, the first for the archipelago, his conclusion was that the terraces were both agricultural and defensive, and they were abandoned when they reached a point of 'diminishing returns', with the soils being exhausted and left fallow (Osborne 1966:151, 155). Lucking (1984) looked for more direct evidence for agriculture in her study, but conceded no direct evidence was recovered, with little support in botanical surveys and Palauan land-use terminology. Yet she continued to support the agricultural argument, with the morphology of two types of terraces - back-sloping and sloping - declared 'ideally suited' for 
cultivating crops, due to their water-holding capabilities (Lucking 1984:164). The top terraces - crowns and brims - were seen as defensive, which coincides with Osborne's argument. A team from Southern Illinois University at Carbondale made further interpretations of Palauan prehistory following a small excavation programme (Masse et al. 1984). Here, terraces were said to have been constructed at the beginning of a 'three phase' settlement chronology, about AD $800-1000$, in a time of agricultural intensification, a response to population growth outstripping the productivity of wetland pond-fields (Masse et al. 1984). This intensified system was part of the defensive element of a regional system 'imbued with competition and political strife' (Masse et al. 1984). Thus, crowns and terraces were also seen as defensive.

More recently, Cultural Resource Management (CRM) based projects have used new investigative techniques to understand the earthworks, and Palau's settlement history as a whole. The main wealth of new data stems from work by the International Archaeological Research Institute Incorporated (IARII) on the Compact Road Project (CRP). During Phase I, a range of excavation methods led to a general interpretation appearing 'to support the proposed shift from agricultural to defensive to residential use of terraces over time, although when and how this happened is still unclear' (Liston 1999:24). Phase II analyses were more intensive, and aimed to provide answers on chronology and mechanisms precipitating the transformation in settlement pattern (Liston 1999:226). The earthworks were re-analysed typologically and split into two groups: 'modified terrain' and 'modified ridges and slopes' (see Liston 1999 for further details). In summary, modified hilltops, including crowns and brims, were considered defensive, but formed during initial landscape modification, not later additions (contra Osborne 1966; Masse et al. 1984). These 'fortified polities' (Liston and Tuggle 2001:8) incorporated terraces which were considered to have had multiple functions: agriculture and habitation, but also ritual and burial (based on new evidence). Liston (1999:369) placed the earthworks within a regional settlement system: 'the long duration of terrace use (c. $1500 \mathrm{yrs)} \mathrm{suggests} \mathrm{the} \mathrm{strong} \mathrm{possibility}$ of functional roles evolving to suit the needs of changing communities over time'.

Wickler's (2002) research followed on from this. Using the results from IARII investigations, Wickler introduced a 'cultural landscape study'. Incorporating new palaeoenvironmental evidence from the study of Athens and Ward (1999, 2001), Wickler looked at landscape transformation from the first signs of land use, to patterns in 'surge and decline' savanna indicators to address aspects of terrace construction (Wickler 2002:69). The focus moved from looking for agricultural indicators, to viewing the earthworks as examples of chiefly power, brought about in a period of terrace expansion at a time of conflict characterised by the struggle for socio-political hegemony and power between competing polities (Wickler 2002:82). Wickler claimed that in Ngatpang State, his local-scale study indicated transformation of terraces into systems of stone work villages. Given the evidence of this local-scale study, Wickler didn't support the suggestion the terraces were ever abandoned.

Despite the strong argument for agricultural use of the terraces based largely within defensive polities, analysis of pollen and phytoliths has been limited to just a few small additional archaeological investigations in Palau (CRM projects). The results, though, are largely restricted to more recent periods in Palauan prehistory. This low number of analyses stands in contrast to the extensive use of pollen and phytolith techniques in other Pacific archaeological projects in the past 10 years. Therefore, pollen and phytolith analyses were undertaken here to locate and assess indirect and direct evidence for subsistence practices, and identify and interpret anthropogenic and natural changes in vegetation on, and within, the vicinity of the earthworks. The latter concern is particularly relevant to addressing questions related to the formation of savanna (ked) vegetation in the islands of Micronesia, where researchers have questioned the 
formation of savanna as a result of slash/burn agricultural purposes.

The results discussed in this paper derive from an archaeological investigation in Ngaraard State, Babeldaob, which focused on three dominant earthwork sites: B:NA-4:11 Ngemeduu, B:NA-4:12 Toi Meduu, and B:NA-4:6 Rois. The earthworks in Ngaraard were selected for many reasons. However, of significance is that Ngaraard was investigated by a team (including the author) led by Atholl Anderson in 2000, looking at colonisation issues in the archipelago. Analyses of radiocarbon dates from the colonisation project (Phear et al. 2003; Anderson et al. 2005) were important in helping define the construction sequence of the earthworks, as well as resulting in a revised settlement chronology for Palau (also Clark 2005).

The earthwork investigation looking at Ngemeduu, Toi Meduu and Rois was set within a landscape perspective that addresses both conceptual and physical elements of monumental earthworks (see Phear 2007:18-19). Thus, the research strategy incorporated an excavation programme, with the three sites sampled in 2001. The project aimed ultimately to provide a landscape history for this area of Ngaraard, and as such, incorporated other analytical techniques (such as clay and ceramic analyses), along with the analytical techniques discussed here. Full interpretive results can be found elsewhere (Phear 2007). The aim of this paper is to specifically assesses and discuss evidence for prehistoric landscape vegetative transformations on the ridgeline of Ngaraard, including evidence for subsistence activities, from early settlement to earthwork construction.

\section{Physical background: Palau Islands}

The Republic of Palau is a group of islands in Micronesia, an area which contains more than 2000 islands. Yap and the Republic of Palau, Beluu er a Belau, form the Western Caroline Islands (Figure 1). The Palau archipelago contains more than 300 islands, extending along a 150 $\mathrm{km}$ arc (Figure 2). Situated about $7^{\circ}$ north of the equator, Palau is $900 \mathrm{~km}$ east of Mindanao in the Philippines, and $650 \mathrm{~km}$ from Papua New Guinea in the south.

Most Palauan islands are of uplifted coralline limestone. They're known locally as the 'rock islands', and are located in the centre of the archipelago. Some reasonably large rock islands have high points over $200 \mathrm{~m}$ above sea level, but poorly developed soils with no surface drainage

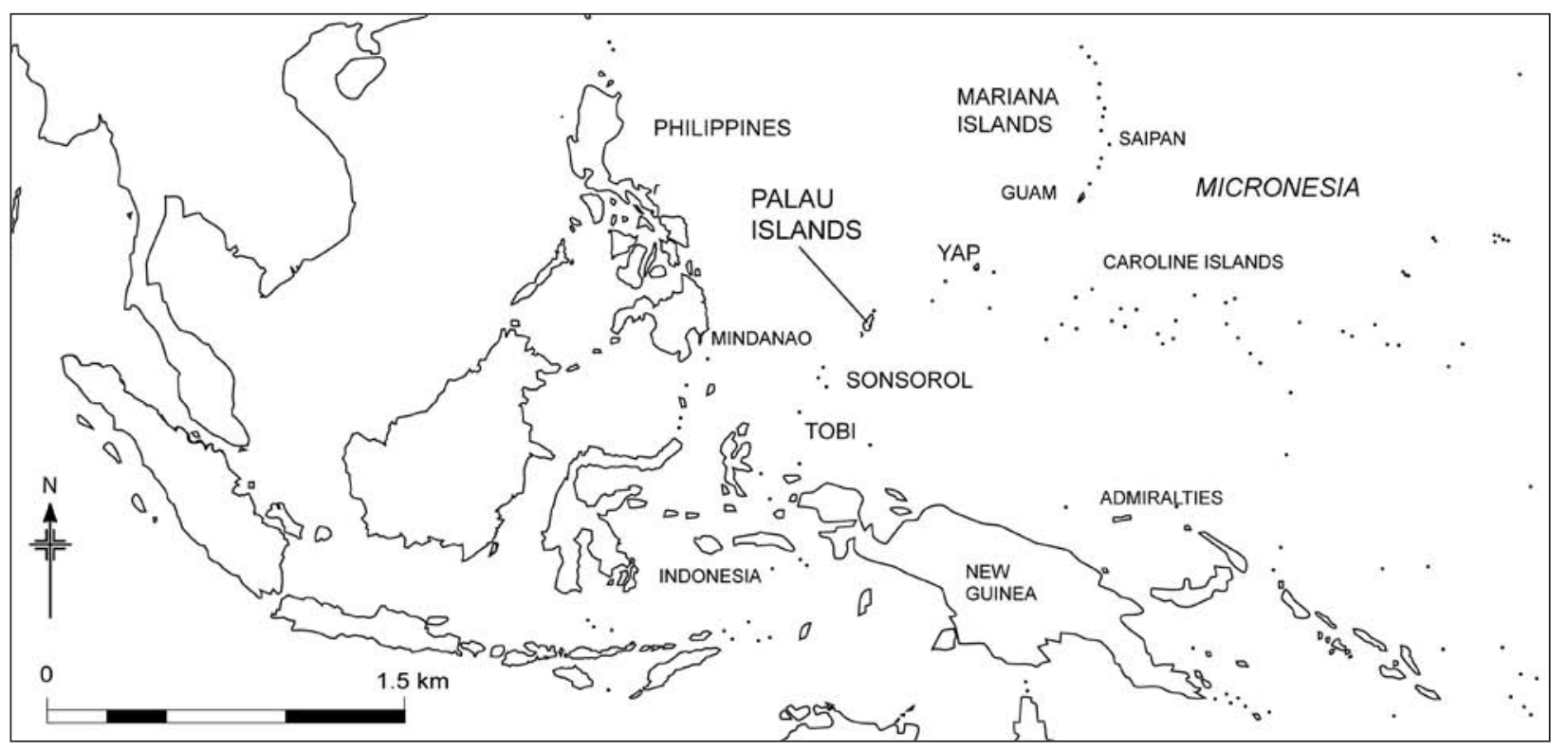

Figure 1. Map of Micronesia. 


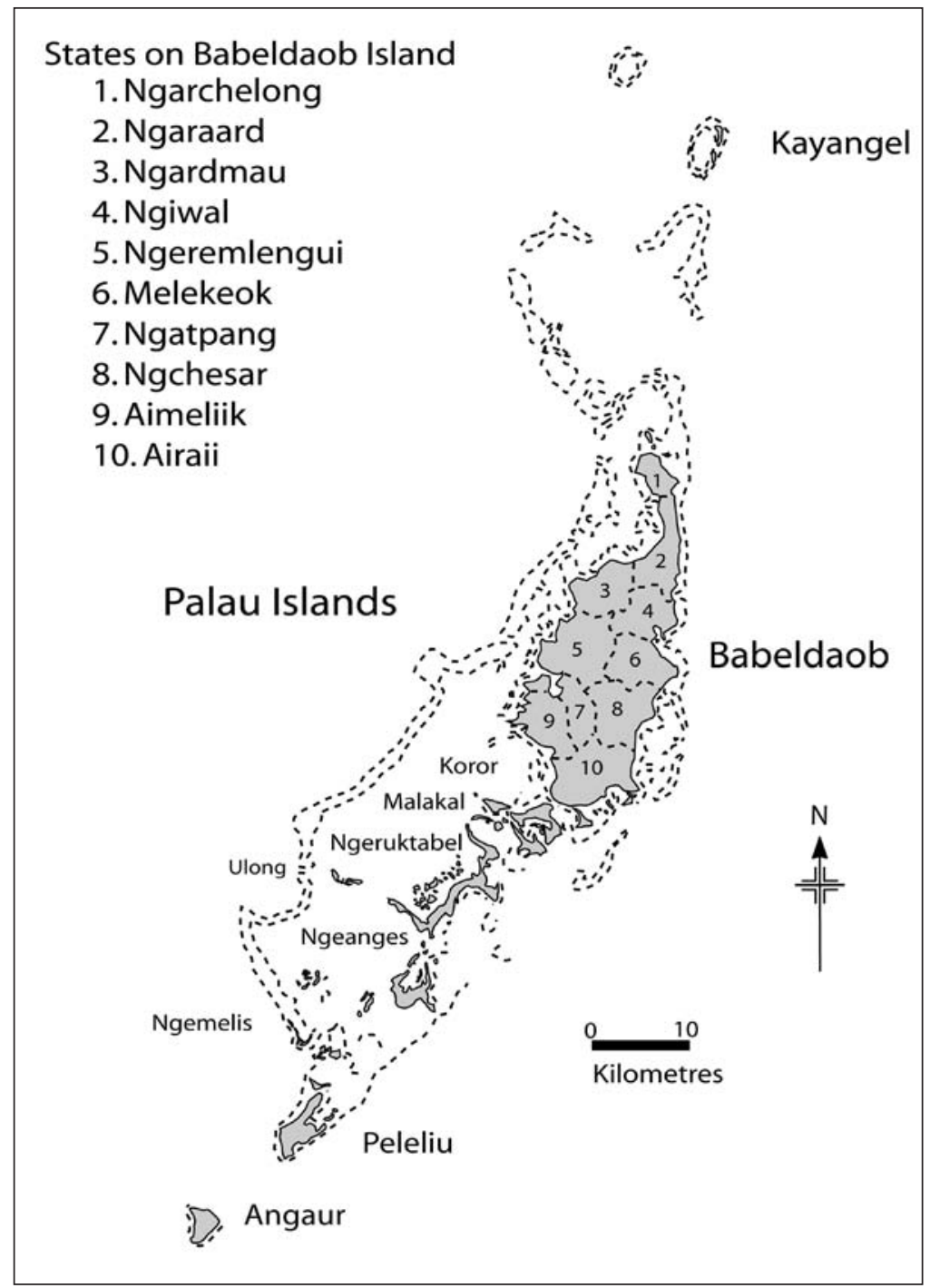

Figure 2. Map of the Republic of Palau.

systems. The islands have distinctive undercuts caused by wave action, and these cuts eventually trigger smaller islands to collapse.

Babeldaob, the largest volcanic island, at $363 \mathrm{~km}^{2}$, represents the majority of Palau's land mass (Figure 2). It has a series of ridge systems that extend north-south, characterised by small, narrow valley systems and coastal plains, with tidal flats and dense mangrove forests. The highest peak on Babeldaob, Rois Ngerekelehuus, is $240 \mathrm{~m}$ asl. The volcanic soils are heavily weathered and form loose, and somewhat unstable, hill slopes.

An extensive blanket of limestone originally covered the volcanic strata of Babeldaob, and only a few remnants can be found (e.g. Oikull). These overlap the volcanic and volcaniclastic strata of the ancient volcanic edifice. The other volcanic islands, Ngerkebesang, Koror, Malakal and the rock islands, are less uplifted remnants of the formerly extensive blanket of Palau limestone. This uplift occurred in the Miocene, and younger limestone forms the chain of islands extending south to Anguar.

Barrier, fringing and patch reefs, comprised of inner and outer reef flats, encircle the islands (except Anguar). The barrier reef, 1-3 km wide, stretches northeast to southwest off the west coast, and is $120 \mathrm{~km}$ long. A $15 \mathrm{~km}$ wide lagoon separates the islands from the reef, and it is here that many of the patch reefs are found. The reef systems of Palau are considered the richest in the Pacific, with the highest species diversity. 


\section{Climate and vegetation}

The tropical climate of Palau undergoes minor changes throughout the year, and has an average annual rainfall of $3730 \mathrm{~mm}$. Temperatures average $27 \mathrm{C}$, with a mean fluctuation of no more than $7 \mathrm{C}$, and a relative humidity of 90 percent at night and $75-80$ percent during the day. Although not in the typhoon belt, Palau endures storms and high winds associated with severe tropical disturbances.

Mueller-Dombois and Fosberg (1998) describe the volcanic half of Palau as possessing a floristically and physiognomically rich array of vegetation compared with the rest of Micronesia, although Yap possesses a similar level of diversity. These two island groups form a 'distinct phytogeographic unit, with many endemic species and the easternmost extensions of several others from the rich Indo-Melanesian flora'. The deeply weathered ancient volcanic islands, which are highly leached, and whose original structure is mostly lost, reflect differing topographical vegetation patterns to limestone islands.

Forest covers 75 percent, and grassland or savanna grassland covers 18 percent of Babeldaob. The volcanic islands also have mangrove and freshwater-swamp forests, strand and lowland vegetation, interior upland forest, and ravine and Riparian forest. The limestone islands are characterised by closed and diverse evergreen forests. These various vegetation zones are home to numerous fauna.

\section{The project}

\section{Site location}

Sites located in Ngaraard State, within the Ngebuked Village area, were sampled: B:NA-4:6 Rois Terrace Complex, B:NA-4:11 Ngemeduu Crown and Terrace complex, and B:NA-4:12 Toi Meduu Crown and Terrace Complex (Figure 3). The construction of the Compact Road has had a significant impact on earthworks in Ngaraard and surrounding traditional villages. Through archaeological investigations within the CRP, IARII has provided a large amount of information on many impacted sites, along with other small investigations (Osborne 1966; Masse and Snyder 1982; Olsudong et al. 2000).

\section{B:NA-4:11 Ngemeduu Crown and Terrace Complex}

Ngemeduu, $181 \mathrm{~m}$ asl, is a prominent modified hillside on the central ridge system in Ngaraard (Figure 4). It has a rectangular crown, with a knoll or 'peak', surrounded by a large terrace, with a steep scarp on its southern extent. Four smaller terraces extend down its northwest (NW) slope, one with a stone alignment. The north side of the site is very steep, with a northeast-facing scarp that extends to the forested lowlands. The west face extends along a secondary ridge, which is intersected by two roads. There are two rectangular depressions on the crown surface: the 'west depression' is $8.5 \mathrm{~m}$ wide (NS) by $10 \mathrm{~m}$, and the 'east depression' is $8 \mathrm{~m}$ by $8 \mathrm{~m}$.

Ten trenches (TR1-TR1i) and one test unit were excavated, encompassing the two depressions, the knoll, the south side of the crown and the surrounding terrace (see Phear 2007: Chapter 5 for excavation details).

\section{B:NA-4:12 Toi Meduu Crown and Terrace Complex}

Toi Meduu is a visually dominant crown and terrace complex immediately south of Ngemeduu (Figure 5). It overlooks the ridge to the south, as well as spurs which extend off the main trunk. The site itself has three crowns, separated by large ditches, one in the northern end of the site, and two to the southwest, which form a slight semi-circle. To their south, a steep slope culminates in a large back-sloping terrace, stretching into the valley below. A large flat terrace 


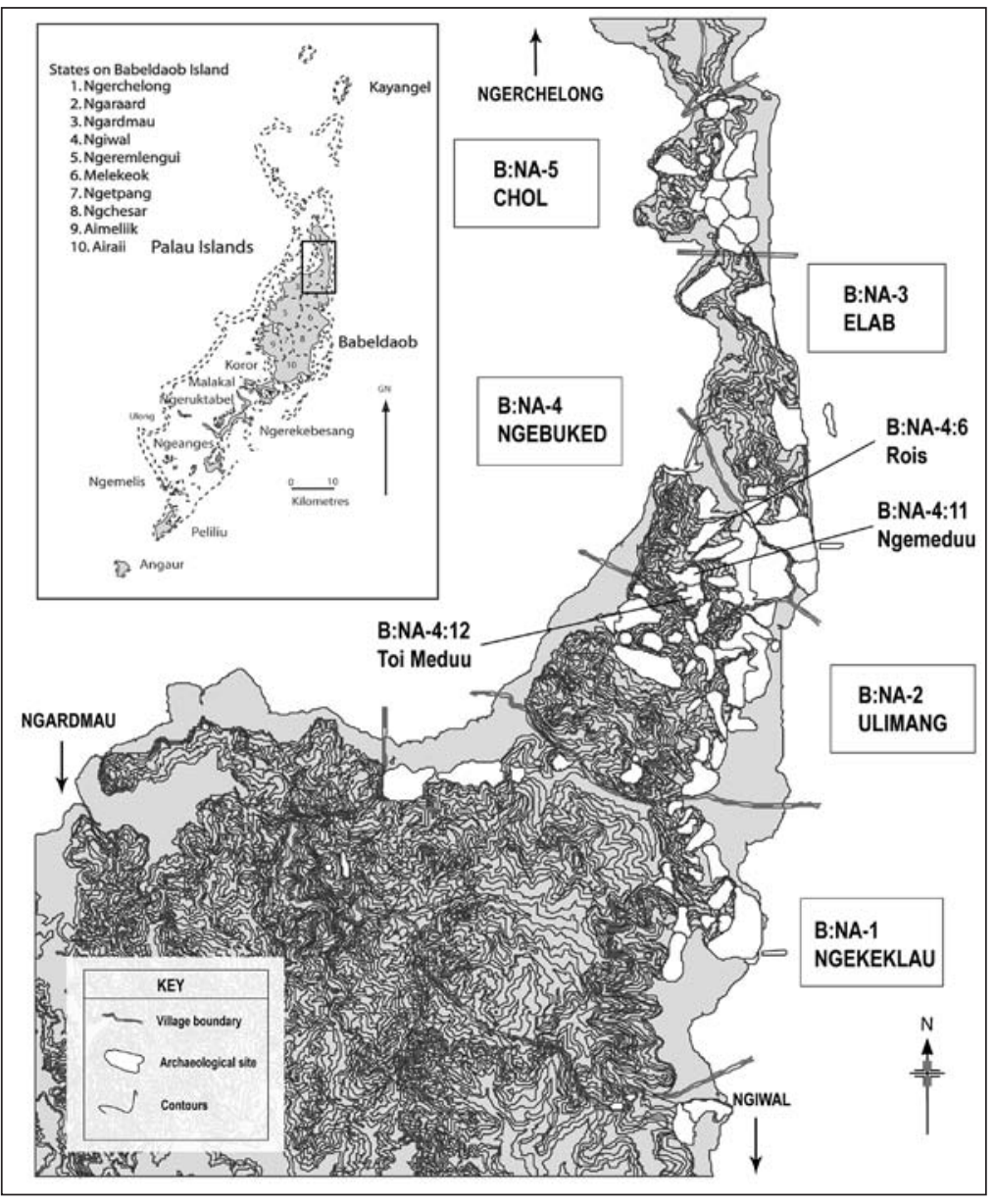

Figure 3. Map of Ngaraard illustrating the three sites investigated (the map has been modified from the BAC GIS database).

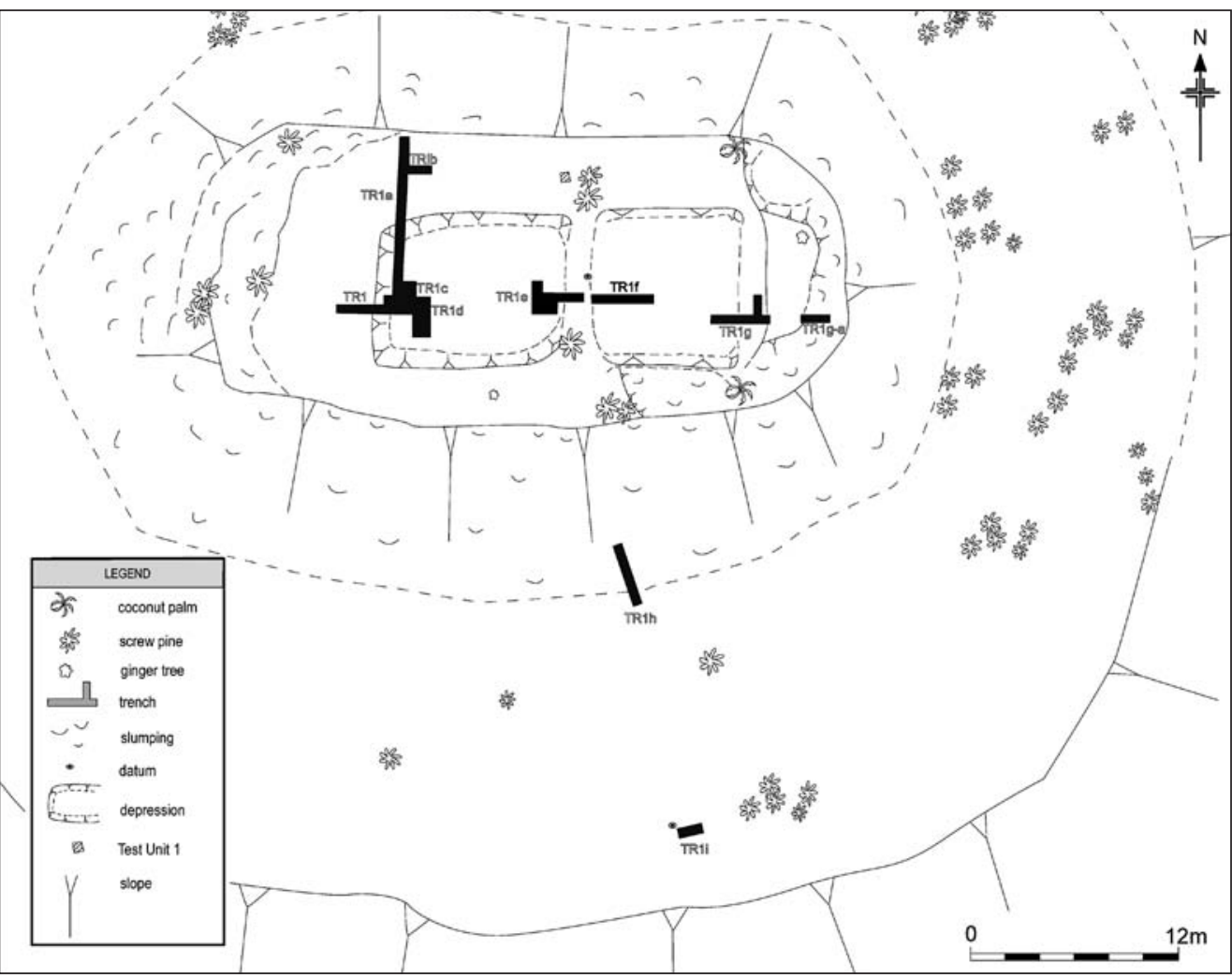

Figure 4. Plan of Ngemeduu with the 10 trenches excavated. 
extends to the north of the westernmost crown, and has some basalt boulders that may have supported a platform.

The west crown, which was sampled, is $9 \mathrm{~m}$ higher than the terrace below. Stonework on the crown surface appears to be of an earlier pre-earthwork type, although it is heavily eroded and its original form is not clear. It most likely represents a past structure. The crown surface has eroded into the ditch, and pottery fragments were present on the surface of the crown, close to the ditch edge. Another stone platform is located on the central crown on a levelled area, with pottery lodged among the stones and eroding from the surface.

Three trenches were excavated - one on the northwest terrace (TR2), one in the ditch separating two crowns (TR5) and one on the back-sloping terrace to the south (TR3).

\section{B:NA-4:6 Rois Terrace Complex}

The Rois terraces are located on a spur between Ngetcherong and Ngebuked traditional villages, extending from the central ridgeline to the northeast of Ngemeduu. The terraces were constructed on a slope, and are considered small or 'slight', with broad surfaces and short risers (Figure 6). The lowest terraces are currently cultivated with taro and cassava. The terrace immediately above these was selected for sampling, as it complemented previous investigations which tested the upper terraces only (see Liston 1999). One trench was placed here (TR4). Slumping is evident at the rear of the terrace, like most of the terraces in the complex. The western extent is currently artificially mounded, due to the dirt road, and the terrace extends a further $4-5 \mathrm{~m}$ beyond the road, to the west. Large amounts of pot sherds were exposed in the road surface next to the terrace.

\section{Pollen and phytolith analysis}

\section{Methodology}

Pollen and phytolith analyses were done to identify indicators of anthropogenic and natural vegetation. Specifically, the aim in this project was to identify vegetation from various soil strata within the earthworks, to give insight into questions of land clearance before earthwork construction (i.e. whether there was savanna present or forest, and when it was cleared). Another aim was to identify direct and indirect evidence of agriculture, although obtaining direct evidence (e.g. Colocasia spp.) is problematic, due to factors influencing dispersal and long-term preservation of Colocasia pollen in soils.

Phytolith analysis provides an indication of plants growing in the immediate area of sampling, because phytoliths are returned to the soil through decay-in-place deposition of parentplant material. With this in mind, the technique was used to attempt to identify evidence of cul-

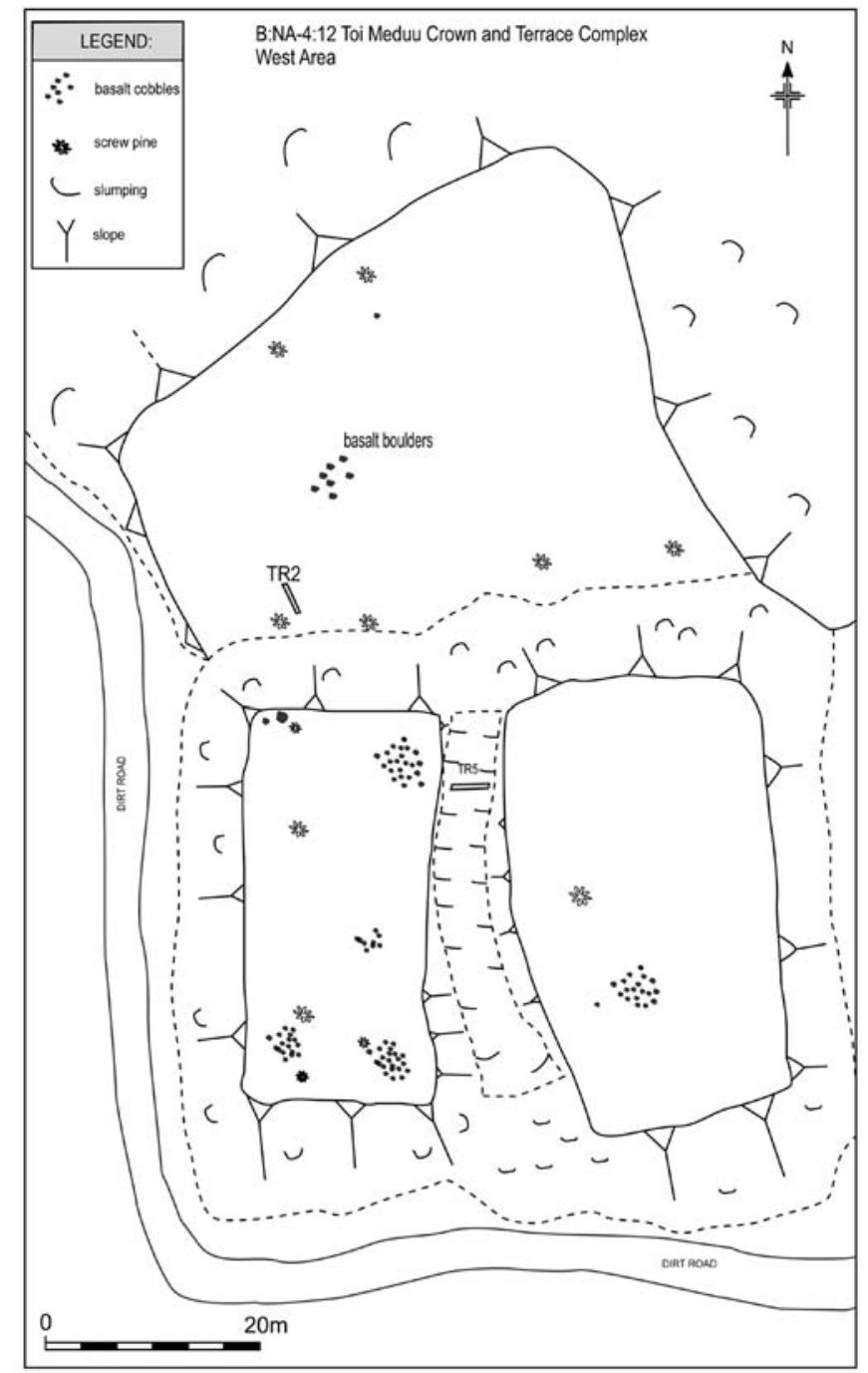

Figure 5. Plan of Toi Meduu with Trenches 2 and 5. 


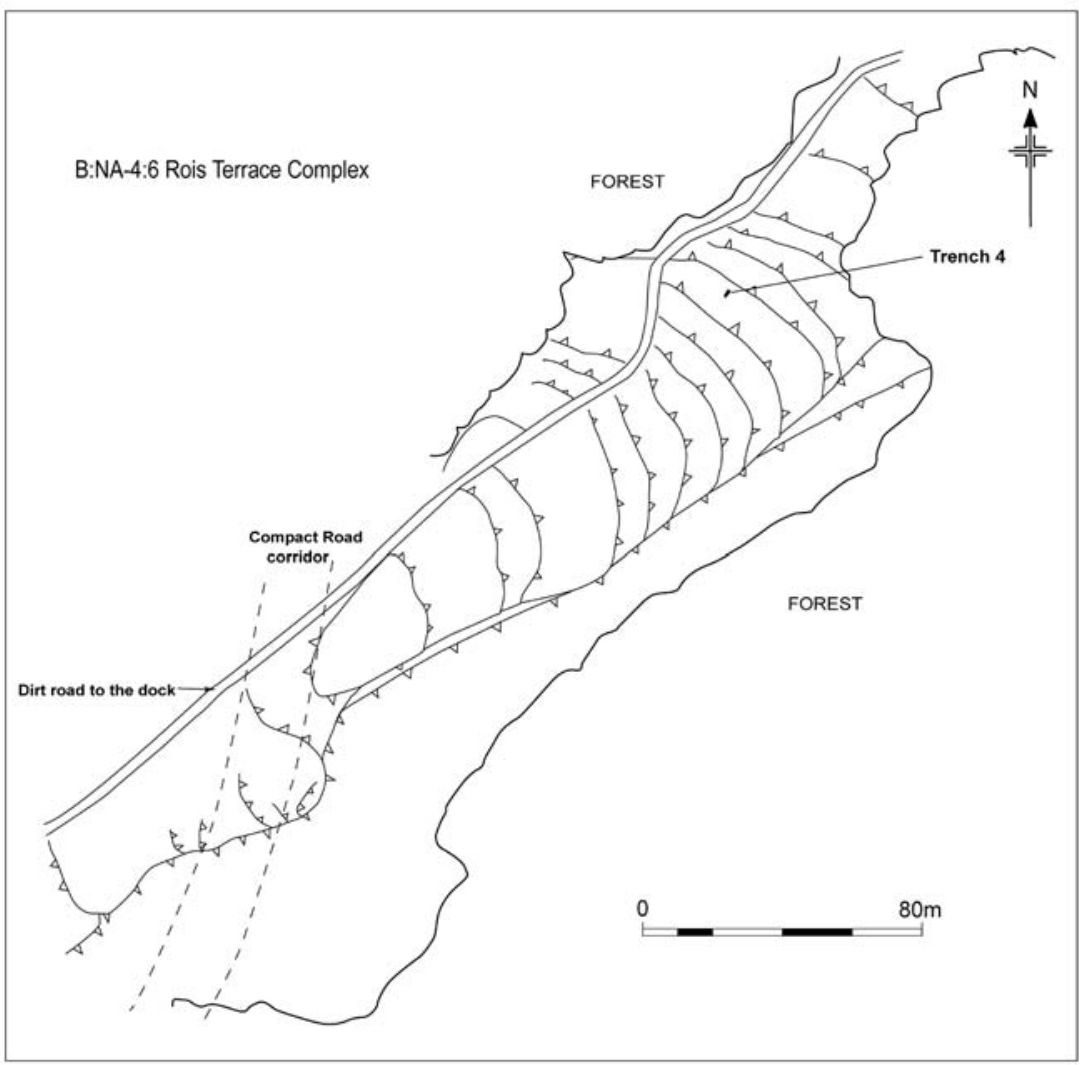

Figure 6. Plan of Rois terraces with Trench 4.

tivated crops in earthwork stratigraphy. Additionally, this method was used to provide information on other indicators of human interaction with the environment, such as the incidence of secondary growth related to clearance.

\section{Phytolith analysis}

Twelve soil samples were sent to J. Parr at the Centre for Geoarchaeology and Palaeoenvironmental Research, School of Environmental Science and Management, Southern Cross University, Australia. Parr used the Perkin-Elmer Multiwave Sample Preparation system for phytolith and starch-grain extraction from each sample. Phytoliths extracted from each were weighed, mounted on to microscope slides and scanned at 400x magnification on an Olympus BH2 microscope. All phytoliths encountered during three transects of a microscope slide were counted, although only one transect was counted for charcoal.

Fossil phytolith types were compared with those stored in a modern phytolith digitalimage database of about 200 species from regionally applicable flora of Papua New Guinea and Australia. Other databases included the CD-ROM and Kealhofer and Piperno. Phytolith sizes were gauged using an ocular micrometer and the individual scale bars on each digital image.

\section{Pollen analysis}

Twenty-one pollen samples were analysed in the Department of Archaeology and Natural History at the Australian National University. All samples followed standard laboratory processing procedures, and Lycopodium pollen was added as a 'foreign' control measure. Once processed, the samples were mounted on to microscope slides and analysed.

Pollen was measured by moving down along a transect, and then repeated in reverse, until all 
transects were completed. A total slide pollen count was completed due to the relatively unknown flora of the area, although a pollen database from Papua New Guinea was consulted. Charcoal counts were made following the methodology of Clark (1982). The results were entered into a Tilia database (version 2.04b) and pollen diagrams were produced using Tiliagraph (version 2.04b). Charcoal counts were also analysed.

\section{Results: B:NA-4:11 Ngemeduu Crown and Terrace Complex}

A complex stratigraphic history was uncovered for the Ngemeduu earthworks. Only the most important stratigraphic results are discussed here.

\section{Crown surface}

The crown surface, immediately outside the west depression, is the youngest chronological surface of the feature. Therefore, Layer II (Figure 7, Table 1) was tested for both pollen and phytoliths (Table 2). The pollen identified represents 'classic' savanna grassland vegetation - e.g. Pandanus sp., fern spores, Polypodiaceae, and Poaceae. The charcoal concentration is low for this layer, although the phytolith charcoal level of abundance is moderate. While the phytolith data indicate a range of plants, their low number does not allow quantification beyond presence/ absence. Grasses (Poaceae) are recorded, and also banana (Musaceae), a tree (Marantaceae), and a starch grain.

\section{West depression}

The layers in the central part of the depression were focused on here (Figure 7), except for LVI. This latter layer was formed through numerous temporal-fill episodes, and had a highly disturbed structure (See Phear 2007:Chapter 6), and was consequently not considered for sampling. From LVIII up to LI, there is a general fluctuation between classic savanna grasslands dominated by Pandanus sp. and grasses (Poaceae), and savanna dominated by the ferns and fern allies, which are disturbance indicators (Table 2). The pollen counts tend to increase vertically in the profile, with LI and LIV illustrating the highest numbers. A few secondary vegetation taxa are recorded in LV-LIV, but they are poorly represented in general. There is a clear variation in charcoal concentrations, with the basal layer (LVIII) and the top layer in the depression (LI) displaying the highest intensities.

The phytolith analysis provides comparable results. No phytoliths were recorded for the lowest two layers, however the grasses and Pandanus sp. observed in LV-LIV support the pollen results. Layer IV displays the most varied range of taxa, with classic savanna, secondary vegetation and disturbance plants present. The fig (Moraceae) and Liliaceae phytoliths are of note, though only one of each was found. The presence of Arecaceae in LV and LIV may indicate betel-palm growth on site. Little charcoal was recorded, although the presence of charred phytoliths suggests local fire activity (discussed later in the paper). The high concentration of charcoal recorded in the pollen record for LVIII is replicated in the phytolith charcoal results.

\section{Encircling terrace}

Pollen analysis was undertaken on samples from LIV and LIII in Trench 1i (Figure 8, Table 3). These layers were brought to the site as terrace fill, and thus formed terrace surfaces. The results reflect savanna grassland (Table 1), although LIV is dominated more by ferns/fern allies and LIII by Poaceae and Pandanus sp., the more classic grassland taxa. The pollen count is significantly higher for LIV, and so, too, the charcoal concentration. 
Table 1. Stratigraphic descriptions for Trench 1a, Ngemeduu.

\begin{tabular}{|c|c|}
\hline \multicolumn{2}{|c|}{ Ngemeduu (B:NA-4:11) Trench 1a (TR1a) } \\
\hline Layer & Description \\
\hline I & $\begin{array}{l}\text { 7.5YR 4/4 Brown clay loam, average thickness } 10 \mathrm{~cm} \text {, friable, many roots all sizes, begins just outside of depression edge, } \\
\text { discontinuous. }\end{array}$ \\
\hline la & Organic A horizon, top $2 \mathrm{~cm}$, located only in the depression, many roots. \\
\hline ॥ & 5YR 4/4 Reddish brown clay, average thickness $30 \mathrm{~cm}$, subangular blocky, roots common fine to coarse, quite friable, discontinuous. \\
\hline III & $\begin{array}{l}\text { 10YR } 4 / 4 \text { Dark yellowish brown silty clay, average thickness } 12 \mathrm{~cm} \text {, firm, roots common medium sized, }>1 \mathrm{~mm} \text { sized charcoal flecks, } \\
\text { discontinuous. }\end{array}$ \\
\hline IIlla & $\begin{array}{l}\text { 7.5YR } 5 / 8 \text { Strong brown with grey flecks silty clay, average thickness } 10 \mathrm{~cm} \text {, subangular blocky, firm, few roots micro sized, } \\
\text { discontinuous. }\end{array}$ \\
\hline IV & 10YR 4/3 Brown clay silt, average thickness $12 \mathrm{~cm}$, subangular blocky, firm, abundant $>1 \mathrm{~mm}$ sized charcoal flecks, discontinuous. \\
\hline IVb & $\begin{array}{l}\text { 10YR } 6 / 6 \text { Brownish yellow silty clay, average thickness } 10 \mathrm{~cm} \text {, subangular blocky, quite firm, roots common fine to medium sized, } \\
\text { many }>1 \mathrm{~mm} \text { charcoal flecks. }\end{array}$ \\
\hline V & $\begin{array}{l}7.5 Y R 5 / 8 \text { Strong brown clay, average thickness } 25 \mathrm{~cm} \text {, firm though structureless, few roots micro sized, few charcoal flecks, lower } \\
\text { boundary defined by iron pan, some sherds. }\end{array}$ \\
\hline $\mathrm{VI}$ & $\begin{array}{l}\text { 2.5YR } 3 / 3 \text { Dark reddish brown clay with white and pink mottles of saprolite, average thickness } 2 \mathrm{~m} \text {, many sherds and charcoal, mixed } \\
\text { with degrading more friable saprolite present in clasts and brown rather structureless clay, micro sized roots, upper boundary defined } \\
\text { by iron pan in depression only. }\end{array}$ \\
\hline VII & $\begin{array}{l}\text { 5YR 4/4 Reddish brown clay, average thickness } 30 \mathrm{~cm} \text {, plastic but firm, abundant charcoal flecking with some larger charcoal samples } \\
\text { present, subangular blocky, consistent boundary, highly eroded bauxite nodules, some micro sized roots, small } \\
\text { basalt pebbles, abundant sherds. }\end{array}$ \\
\hline VIII & $\begin{array}{l}\text { 5YR 4/3 Reddish brown clay, average thickness } 1.5 \mathrm{~m} \text {, subangular blocky, charcoal flecking frequent with larger samples present, } \\
\text { small saprolite clasts and some slight mixing with basal saprolite at boundary, many sherds though frequency decreases with depth, } \\
\text { a few bauxite pebbles. }\end{array}$ \\
\hline IX & C Horizon, Saprolite. \\
\hline
\end{tabular}

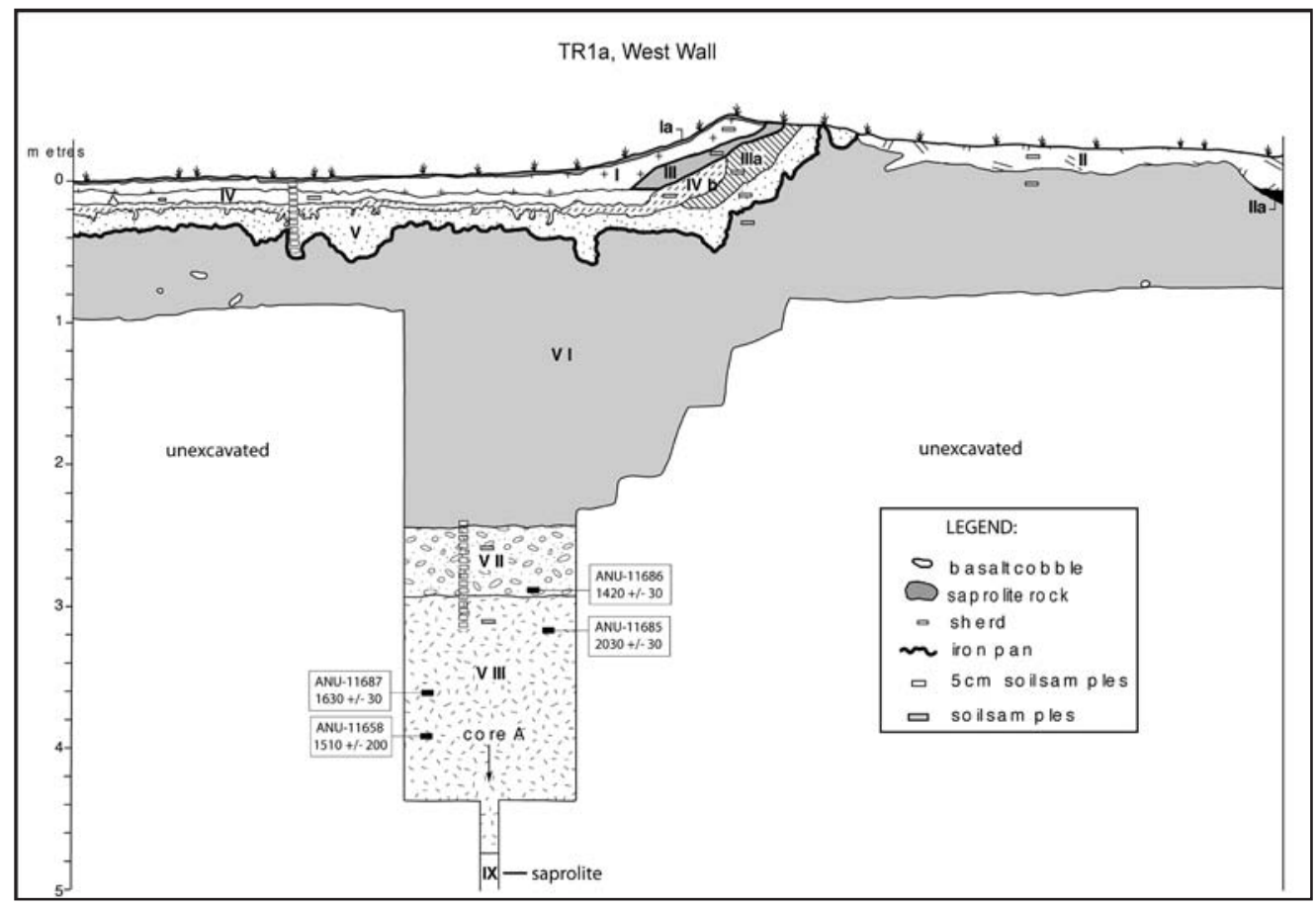

Figure 7. Main stratigraphic diagram for the crown and west depression of Ngemeduu. 
Table 2. Illustrates the pollen percentages and charcoal concentrations (top), and phytolith and charcoal abundance (bottom) for Ngemeduu (B:NA-4:11).

\begin{tabular}{|c|c|c|c|c|c|c|c|c|c|}
\hline Microfossil & TR1/LI & TR1/LII & TR1/LIV & TR1/LIVb & TR1/LV & TR1a/LVII & TR1a/LVIII & TR1i/LIII & TR1i/LIV \\
\hline \multicolumn{10}{|l|}{ Pollen identified: } \\
\hline Pandanus sp. & 23.8 & 17.0 & 27.5 & 26.2 & 37.4 & 0.0 & 2.1 & 10.4 & 0.0 \\
\hline Trilete spores & 12.6 & 7.5 & 17.4 & 35.4 & 33.0 & 15.3 & 31.9 & 8.3 & 3.3 \\
\hline Monolete spores & 3.8 & 35.8 & 3.6 & 1.2 & 18.7 & 81.4 & 48.9 & 43.8 & 94.4 \\
\hline Poaceae & 46.4 & 5.7 & 38.1 & 17.7 & 3.3 & 0.0 & 2.1 & 10.4 & 2.2 \\
\hline Polypodiaceae & 2.5 & 22.6 & 0.4 & 1.2 & 1.1 & 0.0 & 1.1 & 2.1 & 0.0 \\
\hline Asteraceae & 1.3 & 0.0 & 1.6 & 11.6 & 1.1 & 0.0 & 2.1 & 2.1 & 0.0 \\
\hline Macaranga sp. & 0.4 & 0.0 & 0.8 & 0.0 & 2.2 & 0.0 & 0.0 & 0.0 & 0.0 \\
\hline Casuarina & 1.3 & 0.0 & 0.0 & 0.0 & 0.0 & 0.0 & 1.1 & 0.0 & 0.0 \\
\hline Polygonum & 2.1 & 0.0 & 0.0 & 4.3 & 0.0 & 0.0 & 0.0 & 8.3 & 0.0 \\
\hline Total pollen sum \# & 239.0 & 53.0 & 247.0 & 164.0 & 91.0 & 59.0 & 94.0 & 48.0 & 90.0 \\
\hline $\begin{array}{l}\text { Charcoal concentrations on } \\
\text { pollen slides \#\# }\end{array}$ & 12.03 & 0.30 & 2.89 & 4.8 & 1.51 & 0.63 & 10.30 & 0.41 & 3.32 \\
\hline \multicolumn{10}{|l|}{ Phytoliths identified: } \\
\hline Andaintaceae & & & $x$ & & & & & & \\
\hline Arecaceae & & & $x$ & & $x$ & & & & \\
\hline Areistolachaeae & & & $x$ & & & & & & \\
\hline Compositae & & & $x$ & & & & & & \\
\hline Cyperaceae & & & $x$ & & & & & & \\
\hline Liliaceae & & & $x$ & & & & & & \\
\hline Magnoliaceae & & & & & & & & & \\
\hline Marantaceae & & $x$ & & & & & & & \\
\hline Moraceae & & & $x$ & & & & & & \\
\hline Musaceae & & $x$ & & & & & & & \\
\hline Pandanaceae & & & & & $x$ & & & & \\
\hline Poaceae & & $x$ & $x$ & $x$ & & & & & \\
\hline Urticaeae & & & $x$ & & & & & & \\
\hline Diatoms & & & & & & & & & \\
\hline Starch & & $x$ & & & & & & & \\
\hline Charcoal on phytolith slides \#\#\# & & ** & * & * & * & * & $* * *$ & & \\
\hline Charred Phytoliths & & $x$ & $x$ & $x$ & $x$ & & & & \\
\hline
\end{tabular}

\# includes sum of all pollen and spores counted in sample.

\#\# point count method.

\#\#\# abundance of charcoal to phytolith counts.

Shaded $=$ not analysed.

$X=$ present.

* $=$ relative abundance scale. 
Table 3. Stratigraphic descriptions for Trench 1i, Ngemeduu.

\begin{tabular}{|c|c|}
\hline \multicolumn{2}{|c|}{ Ngemeduu (B:NA-4:11) Trench 1i (TR1i) } \\
\hline Layer & Description \\
\hline I & 7.5YR 4/4 Brown clay, A horizon, average thickness $5 \mathrm{~cm}$, many roots of all sizes, firm, humic layer. \\
\hline II & $\begin{array}{l}\text { 5YR 4/4 Reddish brown silty clay, average thickness } 40 \mathrm{~cm} \text {, friable, some }>1 \mathrm{~mm} \text { sized charcoal samples, many roots all sizes, saprolite } \\
\text { clasts mixed throughout, same erosional layer as TR1h. }\end{array}$ \\
\hline IV & $\begin{array}{l}\text { 5YR 4/4 Reddish brown clay with some pink saprolite flecking, average thickness } 50 \mathrm{~cm} \text {, compact, subangular blocky, roots of small sizes, } \\
\text { many small saprolite clasts and } 2-5 \mathrm{~cm} \text { sized saprolite rocks, some sherds and charcoal flecks, many manganese nodules, leveling layer. }\end{array}$ \\
\hline IVa & 7.5YR 4/4 Brown clay mixed with saprolite breccia, average thickness $6 \mathrm{~cm}$, likely formation of B horizon in progress. \\
\hline V & C Horizon, Saprolite. \\
\hline
\end{tabular}

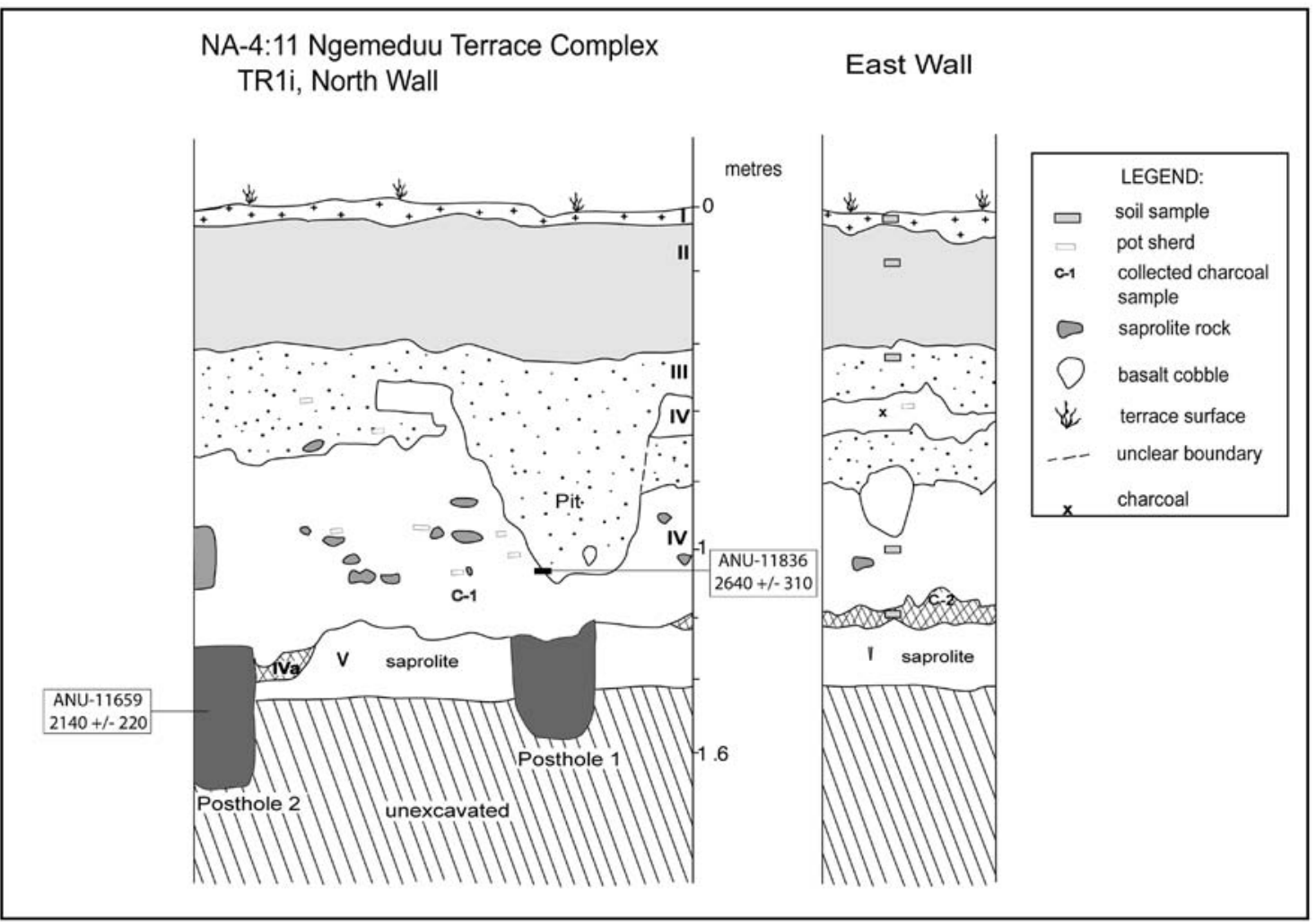

Figure 8. Main stratigraphic diagram for Trench 1i.

\section{Results: B:NA-4:12 Toi Meduu Crown and Terrace Complex}

Northwest terrace

Soil samples from LIII and LII were analysed (Figure 9, Table 4, Table 5). Both the layers are fills, forming the terrace surface at differing stages. A similar pattern to the terrace at Ngemeduu is observed, with LIII (forming the initial terrace) exhibiting a higher percentage of ferns/fern allies, and LII higher in Pandanus sp. and Poaceae percentages, the classic savanna taxa. However, the reverse picture is seen in the pollen sum and charcoal concentrations, with LII exhibiting higher levels of both charcoal and pollen compared with LIII. No phytoliths were recorded from LIII. The charcoal count for the phytolith analysis is exceptionally low, although a Synedra ulna fresh-water diatom was identified. Diatoms are microscopic forms of aquatic and sub-aquatic 
algae, inhabiting wetlands, lakes, estuaries and oceans. When they are present in archaeological contexts, they indicate water sources in the vicinity. Synedra ulna, an epilithic and pennate diatom, grows best in the presence of nitrates, and prefers to live in habitats with a $\mathrm{pH}$ above 7 (an alkalibionte form). They are most commonly found in puddles or pooled water in variable locations. The implications of diatoms in these samples is examined below.

\section{Back-sloping terrace}

The pollen record for Layer III of TR3 (Table 5), the main layer identified, reflects the dominance of the ferns/fern allies, with virtually no grasses represented and only a small percentage of Pandanus sp. pollen. The total pollen count is low, and the pollen charcoal levels moderate. In contrast, no charred material was observed in the phytolith sample, nor identifiable phytoliths. Three Synedra ulna fresh-water diatoms were also recorded in this terrace.

\section{West ditch}

The two main secondary fill layers (LVI and LVII) were tested for pollen (Figure 10, Table 5, Table 6). Both layers have low overall pollen counts. The ferns/fern allies dominate each layer, and there is a clear absence of grasses and an extremely low percentage of Pandanus sp. pollen. Charcoal counts are also minimal, with a slightly higher count recorded for LVII than LVI. This charcoal pattern is replicated in the phytolith charcoal abundance levels.

Table 4. Stratigraphic descriptions for Trench 2, Toi Meduu.

\begin{tabular}{|c|c|}
\hline \multicolumn{2}{|c|}{ Toi Meduu (B:NA-4:12) Trench 2 (TR2) } \\
\hline Layer & Description \\
\hline I & $\begin{array}{l}\text { 5YR 4/3 Reddish brown silty loam, organic A horizon, average thickness } 5 \mathrm{~cm} \text {, clear lower boundary, smooth, moderate subangular blocky } \\
\text { medium sized peds, some charcoal flecking, friable, many roots, all diameters. }\end{array}$ \\
\hline ॥ & $\begin{array}{l}\text { 5YR 4/4 Reddish brown clay, average thickness } 5 \mathrm{~cm} \text {, clear lower boundary, smooth, medium blocky peds, common roots, fine to medium } \\
\text { sized, loose, two sherds. }\end{array}$ \\
\hline III & $\begin{array}{l}\text { 5YR 5/6 Yellowish red clay with some pink, white and yellow mottling (saprolite), average thickness } 40 \mathrm{~cm} \text {, clear smooth boundary, weak } \\
\text { subangular-blocky medium sized peds, some charcoal flecks, common fine roots, firm. }\end{array}$ \\
\hline IV & C Horizon, Saprolite. \\
\hline
\end{tabular}

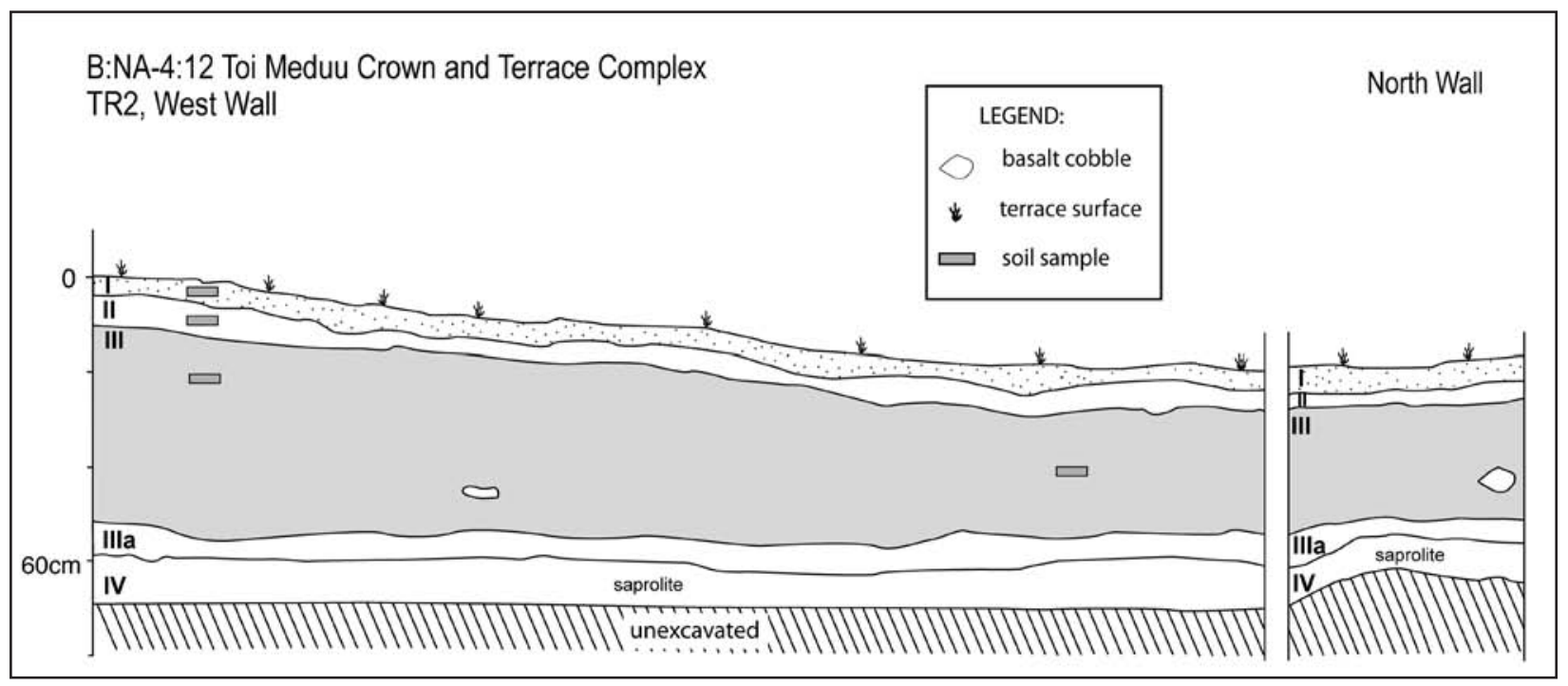

Figure 9. Stratigraphic diagram for Trench 2. 
Table 5. Illustrates the pollen percentages and charcoal concentrations (top), and phytolith and charcoal abundance (bottom) for Toi Meduu (B:NA-4:12).

\begin{tabular}{|c|c|c|c|c|c|}
\hline Microfossil & TR2/LII & TR2/LIII & TR3/LIII & TR5/LVI & TR5/LVII \\
\hline \multicolumn{6}{|l|}{ Pollen identified: } \\
\hline Pandanus sp. & 51.5 & 17.5 & 6.2 & 0.0 & 1.8 \\
\hline Trilete spores & 11.8 & 52.5 & 13.2 & 10.9 & 8.9 \\
\hline Monolete spores & 5.1 & 6.3 & 66.0 & 81.8 & 89.3 \\
\hline Poaceae & 14.7 & 5.0 & 0.7 & 0.0 & 0.0 \\
\hline Polypodiaceae & 0.0 & 0.0 & 0.0 & 3.6 & 0.0 \\
\hline Asteraceae & 0.0 & 0.0 & 0.0 & 0.0 & 0.0 \\
\hline Macaranga sp. & 1.5 & 0.0 & 0.0 & 1.8 & 0.0 \\
\hline Casuarina & 0.0 & 0.0 & 0.0 & 0.0 & 0.0 \\
\hline Polygonum & 7.4 & 15.0 & 12.5 & 1.8 & 0.0 \\
\hline Total pollen Sum\# & 136.0 & 80.0 & 144.0 & 55.0 & 56.0 \\
\hline Charcoal concentrations on pollen slides \#\# & 6.46 & 1.48 & 3.55 & 0.60 & 1.32 \\
\hline \multicolumn{6}{|l|}{ Phytoliths identified: } \\
\hline \multicolumn{6}{|l|}{ Andaintaceae } \\
\hline \multicolumn{6}{|l|}{ Arecaceae } \\
\hline \multicolumn{6}{|l|}{ Areistolachaeae } \\
\hline \multicolumn{6}{|l|}{ Compositae } \\
\hline \multicolumn{6}{|l|}{ Cyperaceae } \\
\hline \multicolumn{6}{|l|}{ Liliaceae } \\
\hline \multicolumn{6}{|l|}{ Magnoliaceae } \\
\hline \multicolumn{6}{|l|}{ Marantaceae } \\
\hline \multicolumn{6}{|l|}{ Moraceae } \\
\hline \multicolumn{6}{|l|}{ Musaceae } \\
\hline \multicolumn{6}{|l|}{ Pandanaceae } \\
\hline \multicolumn{6}{|l|}{ Poaceae } \\
\hline Urticaeae & & & & & \\
\hline Diatoms & & $x$ & $x$ & & \\
\hline Starch & & & & * & ** \\
\hline Charcoal on phytolith slides \#\#\# & & * & & & \\
\hline Charred Phytoliths & & & & & \\
\hline
\end{tabular}

\# includes sum of all pollen and spores counted in sample.

\#\# point count method.

\#\#\# abundance of charcoal to phytolith counts.

Shaded $=$ not analysed.

$X=$ present.

${ }^{*}=$ relative abundance scale. 
Table 6. Stratigraphic descriptions for Trench 5, Toi Meduu.

\begin{tabular}{|c|c|}
\hline \multicolumn{2}{|c|}{ Toi Meduu (B:NA-4:11) Trench 5 (TR5) } \\
\hline Layer & Description \\
\hline I & $\begin{array}{l}\text { 10YR } 3 / 2 \text { Very dark greyish brown silty loam, organic A horizon, average thickness } 8 \mathrm{~cm} \text {, clear lower boundary, friable, many tiny } \\
\text { rootlets. }\end{array}$ \\
\hline II & $\begin{array}{l}10 Y R 4 / 2 \text { Dark greyish brown silty loam, average thickness } 20 \mathrm{~cm} \text {, friable, many rootlets, flecked throughout with red, orange black and } \\
\text { white saprolite specks. }\end{array}$ \\
\hline Ila & $\begin{array}{l}\text { 7.5YR } 3 / 4 \text { Dark brown silty clay, average thickness } 15 \mathrm{~cm} \text {, east and west boundary clear, most likely a lense caused by water } \\
\text { concentration. }\end{array}$ \\
\hline III & $\begin{array}{l}7.5 Y R \quad 4 / 4 \text { Brown silty clay, average thickness } 40 \mathrm{~cm} \text {, firm subangular blocky, a few less than } 1 \mathrm{~mm} \text { roots, sparse charcoal, a few small to } \\
\text { medium cobbles, abundant saprolite flecks with a loamy texture. }\end{array}$ \\
\hline Illa & $\begin{array}{l}\text { 7.5YR 4/6 Strong brown clay, average thickness } 21 \mathrm{~cm} \text {, very similar to LIII with less saprolite flecks and a darker colour, some less than } 1 \\
\mathrm{~mm} \text { roots, similar formation as Layer lla. }\end{array}$ \\
\hline IV & $\begin{array}{l}\text { 7.5YR 4/4 Brown silty clay, average thickness } 50 \mathrm{~cm} \text {, similar to Layer III, but with more cobbles and charcoal flecks, some sherds also, } \\
\text { less than } 1 \mathrm{~mm} \text { roots, some saprolite flecks and loamy texture. }\end{array}$ \\
\hline V & $\begin{array}{l}\text { 7.5YR 4/6 Strong brown silty clay, average thickness } 25 \mathrm{~cm} \text {, firm, less saprolite flecking and a higher clay content, faintly mottled with } \\
\text { orange/yellowish matrix indicative of B horizon formation, scattered subangular medium sized cobbles, scattered sherds, less than } 1 \\
\mathrm{~mm} \text { roots, occasional charcoal chunks. }\end{array}$ \\
\hline $\mathrm{VI}$ & $\begin{array}{l}7.5 Y R \quad 4 / 6 \text { and } 5 / 6 \text { Strong brown silty clay, average thickness } 20 \mathrm{~cm} \text {, heavily mottled with the orange/yellow clay indicative of } B \text { horizon } \\
\text { formation, very sparse tiny rootlets, one large cobble. }\end{array}$ \\
\hline VII & $\begin{array}{l}7.5 Y R \text { 4/4 Brown silty clay, average thickness } 20 \mathrm{~cm} \text {, firm, occasional } 2-3 \mathrm{~cm} \text { saprolite clasts, scattered sherds and charcoal, occasional } \\
\text { medium cobbles. }\end{array}$ \\
\hline VIII & 10YR 3/4 Dark yellowish brown with heavy black and yellow mottles, clay, dominated by saprolite mottling. \\
\hline IX & 7.5YR $4 / 4$ and $5 / 6$ Brown and strong brown mixed silty clay, very moist. \\
\hline$x$ & C Horizon, Saprolite. \\
\hline
\end{tabular}

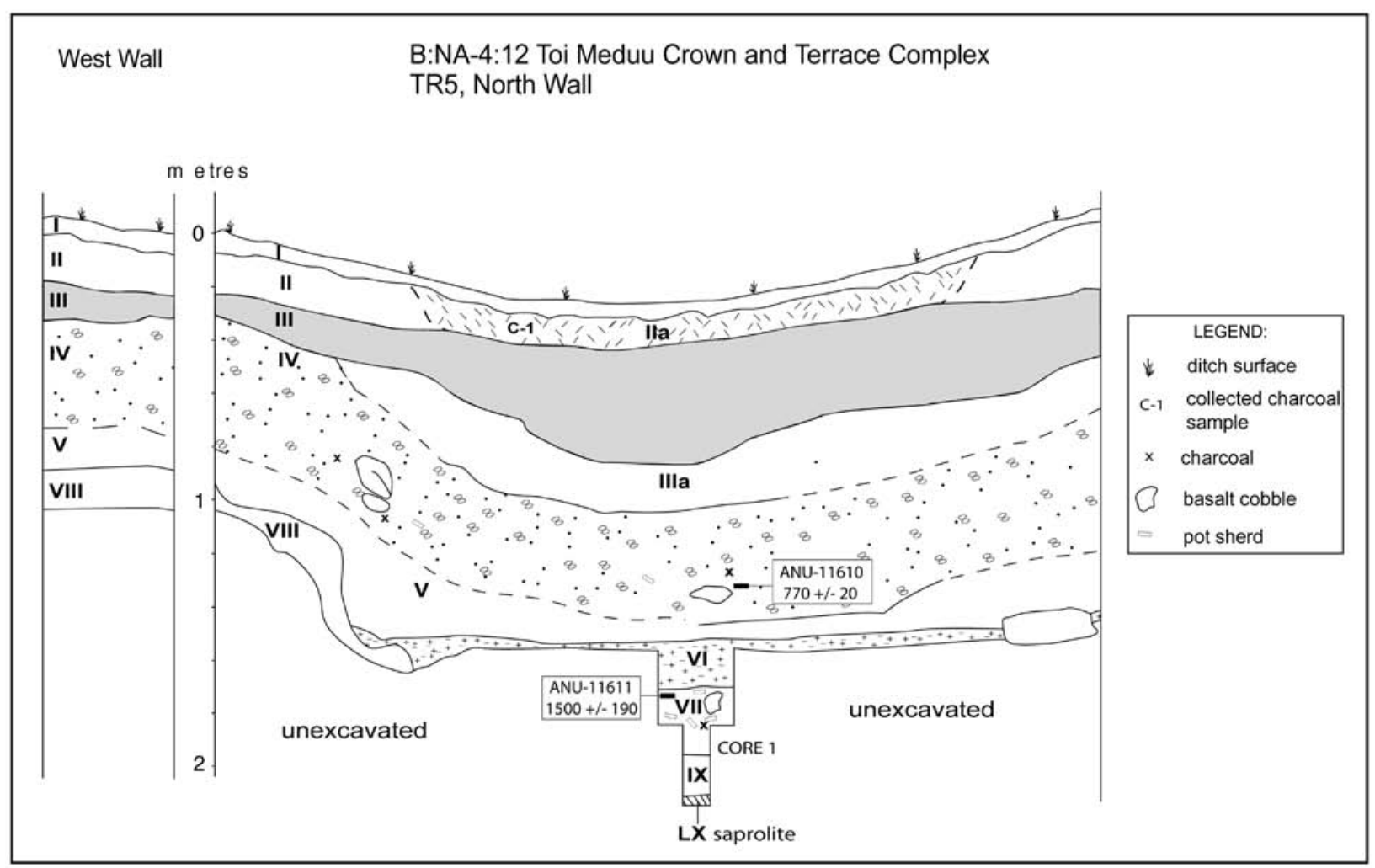

Figure 10. Stratigraphic diagram for Trench 5. 
Table 7. Illustrates the pollen percentages and charcoal concentrations (top), and phytolith and charcoal abundance (bottom) for Rois (B:NA-4:6).

\begin{tabular}{|c|c|c|c|c|c|c|c|}
\hline Microfossil & TR4/LI & TR4/LII & TR4/LIII & TR4/LIIIa & TR4/LIV & TR4/LV & TR4/LVI \\
\hline \multicolumn{8}{|l|}{ Pollen identified: } \\
\hline Pandanus sp. & 15.2 & 11.5 & 13.9 & 7.1 & 8.8 & 4.9 & 13.6 \\
\hline Trilete spores & 35.4 & 38.9 & 47.4 & 38.7 & 40.4 & 12.3 & 16.9 \\
\hline Monolete spores & 8.3 & 11.8 & 10.2 & 35.7 & 42.1 & 67.9 & 50.8 \\
\hline Poaceae & 32.3 & 18.2 & 13.9 & 8.3 & 7.0 & 6.2 & 13.6 \\
\hline Polypodiaceae & 0.2 & 0.3 & 0.0 & 0.0 & 0.0 & 0.0 & 0.8 \\
\hline Asteraceae & 0.0 & 0.0 & 0.0 & 0.0 & 0.0 & 0.0 & 0.0 \\
\hline Macaranga sp. & 0.8 & 0.0 & 0.0 & 0.0 & 0.0 & 0.0 & 0.0 \\
\hline Casuarina & 0.0 & 0.0 & 0.0 & 0.6 & 0.0 & 0.0 & 0.8 \\
\hline Polygonum & 6.3 & 16.9 & 12.4 & 168.0 & 0.0 & 6.2 & 0.0 \\
\hline Total pollen Sum \# & 480.0 & 296.0 & 137.0 & 4.08 & 57.0 & 81.0 & 118.0 \\
\hline $\begin{array}{l}\text { Charcoal concentrations on } \\
\text { pollen slides \#\# }\end{array}$ & 13.02 & 6.74 & 3.87 & 7.1 & 1.05 & 4.72 & 1.49 \\
\hline \multicolumn{8}{|l|}{ Phytoliths identified: } \\
\hline Andaintaceae & & & & & & & \\
\hline Arecaceae & & & & & & & \\
\hline Areistolachaeae & & & & & & & \\
\hline Compositae & & & & & & & \\
\hline Cyperaceae & & & & & & & \\
\hline Liliaceae & & & & & & & \\
\hline Magnoliaceae & & & $x$ & & & & \\
\hline Marantaceae & & & & & & & \\
\hline Moraceae & & & & & & & \\
\hline Musaceae & & & & & & & \\
\hline Pandanaceae & & & & & & & \\
\hline Poaceae & & & $x$ & & & & \\
\hline Urticaeae & & & & & & & \\
\hline Diatoms & & & & & & & \\
\hline Starch & & & & & & & \\
\hline Charcoal on phytolith slides \#\# & & & * & & & * & \\
\hline Charred Phytoliths & & & $x$ & & & & \\
\hline
\end{tabular}

\# includes sum of all pollen and spores counted in sample.

\#\# point count method.

\#\#\# abundance of charcoal to phytolith counts.

Shaded =not analysed.

$X=$ present.

* $=$ relative abundance scale. 


\section{Results: B:NA-4:6 Rois Terrace Complex}

\section{Lower terrace}

The savanna vegetation pattern is also apparent in the Rois pollen record (Figure 11, Table 7 , Table 8). Of note is the classic savanna growth seen in LVI (a 'B' horizon remnant), which changes to a more disturbed savanna in LV. Layers IV and IIIa border on grassy-to-fern, and the classic indicators return in LIII to LI with a higher percentage of Poaceae and Pandanus sp. pollen. The phytolith record accounts for grasses for LIII and one tree phytolith, although

Table 8. Stratigraphic descriptions for Trench 4, Rois.

\begin{tabular}{|c|c|}
\hline \multicolumn{2}{|c|}{ Rois Terrace Complex (B:NA-4:6) Trench 4 (TR4) } \\
\hline Layer & Description \\
\hline I & 7.5YR 4/4 Brown clay, average thickness $6 \mathrm{~cm}$, clear lower boundary, wavy, angular blocky, many roots, all sizes. \\
\hline II & $\begin{array}{l}\text { 5YR 4/4 Reddish brown silty clay, average thickness } 7 \mathrm{~cm} \text {, clear smooth boundary, weak subangular blocky, quite friable, many roots, } \\
\text { medium to coarse, some charcoal flecking. }\end{array}$ \\
\hline III & $\begin{array}{l}5 Y R 5 / 6 \text { Yellowish red silty clay, average thickness } 10 \mathrm{~cm} \text {, clear wavy boundary, weak subangular blocky, common fine roots, firm, a few } \\
\text { sherds. }\end{array}$ \\
\hline Illa & $\begin{array}{l}\text { 5YR } 5 / 4 \text { Reddish brown with white and pink saprolite mottled silty clay, average thickness } 12 \mathrm{~cm} \text {, wavy boundary, weak subangular blocky, } \\
\text { firm, few fine roots, a few sherds. }\end{array}$ \\
\hline IV & $\begin{array}{l}\text { Pink and yellow flecked saprolite dominates with a little } 5 Y R 5 / 4 \text { Reddish brown clay, average thickness } 14 \mathrm{~cm} \text {, abrupt lower boundary, a } \\
\text { few roots. The saprolite is denser at northern end of the trench and less dense at southern end. }\end{array}$ \\
\hline V & $\begin{array}{l}\text { 5YR 4/4 Reddish brown silty clay, average thickness } 40 \mathrm{~cm} \text {, clear smooth boundary, weak subangular blocky, firm, very few fine roots, many } \\
\text { sherds, concentrated at southern end of trench. }\end{array}$ \\
\hline $\mathrm{VI}$ & 5YR 5/6 Yellowish red silty clay, average thickness $12 \mathrm{~cm}$, broken boundary, angular blocky, no roots or charcoal, some sherds, firm. \\
\hline VII & $\begin{array}{l}7.4 \text { YR } 5 / 4 \text { Brown silty clay, average thickness } 14 \mathrm{~cm} \text {, clear smooth boundary, subangular blocky, some micro roots, firm, no charcoal or } \\
\text { pottery. }\end{array}$ \\
\hline VIII & C Horizon, Saprolite. \\
\hline
\end{tabular}

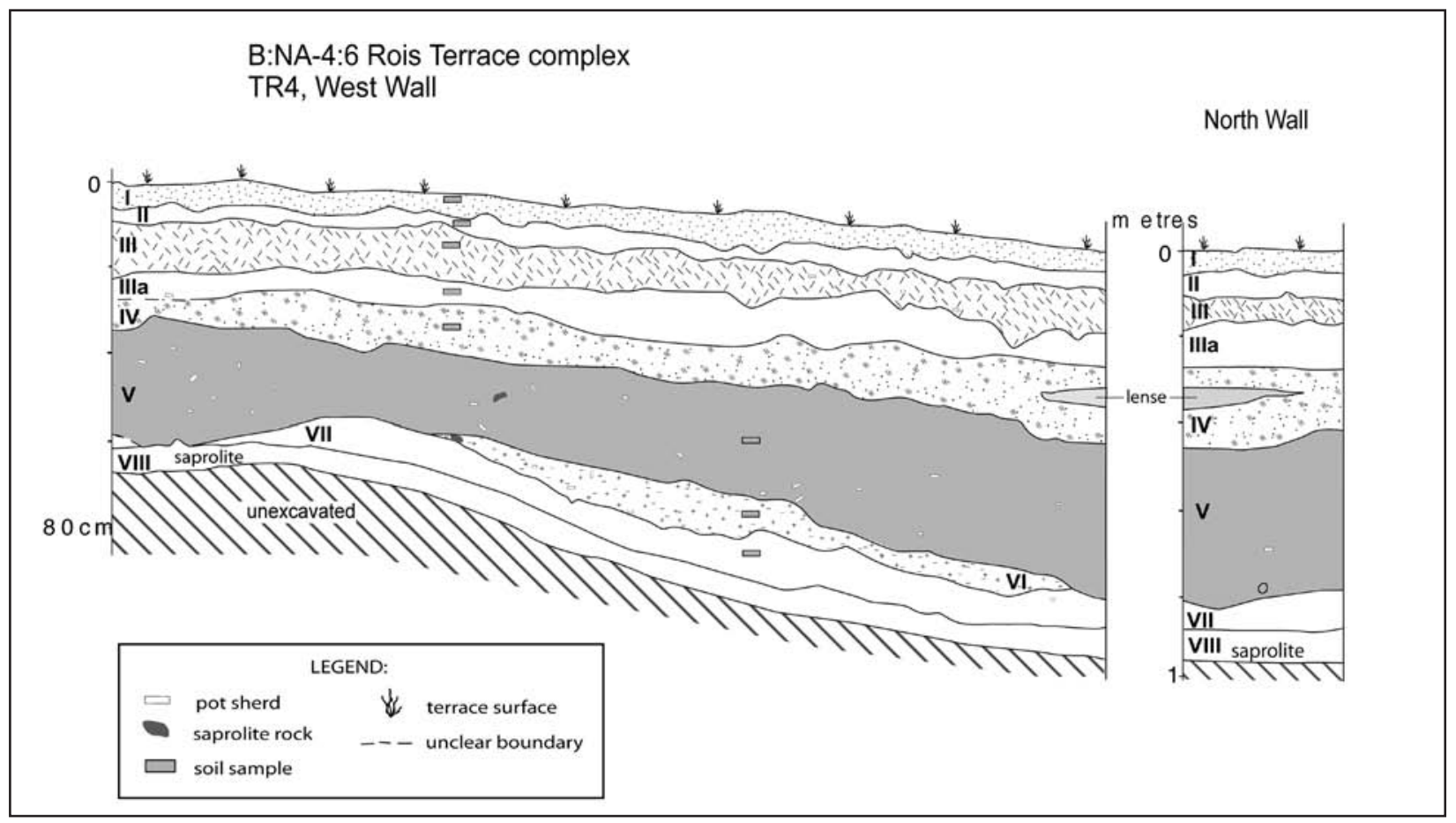

Figure 11. Stratigraphic diagram for Rois. 
LV was phytolith-deficient. In general, charcoal counts on the pollen slides oscillate, with the highest concentrations present in the upper three layers, in parallel with the total pollen sums. Phytolith charcoal was minimal, although a charred phytolith observed in LIII may indicate fire activity on site.

\section{Vegetation pattern}

A detailed discussion of taphonomic and preservation factors can be found elsewhere (Phear 2007:99-100). In general, all samples were phytolith-deficient, and this may be due to factors both cultural and physical. The low number may be due to soil taphonomy (e.g. weathering), or possibly a direct result of vegetation dominated by fern/fern allies, which is not conducive to the growth of phytolith-producing plants (Phear 2007:100). Alternatively, it might be due to the fact that insufficient time elapsed between terrace layer depositions for plant growth to re-establish. Further analysis of this kind is required to fully understand the taphonomic and preservation factors for pollen and phytoliths in the Palauan landscape.

That said, the results are generally indicative of an anthropogenically disturbed landscape during the initial stages of earthwork construction, characterised by a ferns/fern allies-dominated savanna. Once the earthworks were completed/near completion, stable classic grassland was established in both the local environment and on the sites themselves, as none of the plants (from which the pollen and phytoliths derived) contributes significantly to regional pollen rain. Thus, they are likely to have been growing in the immediate vicinity (within $50 \mathrm{~m}$ ) or on each site (Simon Haberle pers comm.). Only Rois displayed a differing pattern, whereby classic savanna was evident in the locale before construction of the lower terrace tested in this project.

With Ngemeduu, the lowest crown layers were formed through initial hilltop earthmoving activities, sometime after 1420 $\pm 30 \mathrm{BP}$ (ANU-11686, (1350(1310)1290 cal. BP), and there is evidence for cultural activities on the hilltop before construction at 2140 220 BP (ANU-11659, $2740(2140,2140,2120) 1570 \mathrm{cal}$. BP). Here we see a disturbed savanna vegetation pattern. High levels of charcoal in LVIII (both pollen and phytolith) suggest land-clearance activities consistent with the initial earthmoving activities. By the time LV was deposited, the landscape had changed to classic savanna. While there is evidence in LIVb for fire activities on site, this may indicate localised burning events. The same pattern is observed in the encircling terrace, whereby the charcoal concentrations coincide with pollen indicative of disturbance, and therefore vegetation clearance through burning appears to have played a role in early terrace formation.

High fractions of Poaceae and Pandanus in the upper layers of the crown indicate a more stable grassland environment, and the phytolith results also support this result, with classic savanna indicators, and also others (e.g. Liliaceae - Cordyline sp., usually grown in coastal plains and around gardens). The Compostiteae may be related to plant growth incorporated with mulching materials. However, it is obvious that no root-crop phytoliths (nor pollen) were present in the samples. Furthermore, as only one phytolith per 'possible' food plant was noted, any conclusion focused on subsistence activities would be rather nebulous at this stage.

Toi Meduu is the older site, with a radiocarbon determination of $1500 \pm 190 \mathrm{BP}$ (ANU-11611, 1820(1390, 1360, 1350)990 cal. BP), documenting cultural activity on the west crown which has eroded into the ditch. The vegetation pattern is similar to Ngemeduu, although the charcoal concentrations are remarkably low, except for two layers in the terrace. Both the terraces reflect a dominance of ferns/fern allies in their most disturbed layers, and the charcoal counts indicate regional fire activity. This is also reflected in the Secondary phase layers (LVI and LVII) in the ditch. A unique component of the Toi Meduu record are the diatoms. The immediate explanation is that both terraces must have had pooled water at some point in order 
for Synedra ulna to have grown. If so, one would have expected diatoms to have been found in the depression profiles of Ngemeduu, and they were not. Alternatively, the diatoms might have been deposited in the original soil matrix of the terrace layers, or through direct animal defecation. Further investigation of diatoms in archaeological contexts is required to clarify such depositional issues.

In sum, the general consistency in the growth of the fern/fern allies is indicative of a disturbed environment throughout the initial construction of each feature of Toi Meduu. With cultural remains recovered from the immediate landscape before Toi Meduu's construction, dating from 1860 to $2150 \mathrm{BP}$ (Welch 2001), it appears people were living in the immediate vicinity and altering the landscape. Stability is reflected only later in Toi Meduu's history, when the soils had regained some nutrients through organic activities and sedimentation, and human clearance activities decreased and/or stopped.

Rois differs slightly from the ridge-top sites, with two different depositional episodes. There is potential indirect evidence for cultivation activities in LIII to LI. Firstly, the wavy layer boundaries are similar to a pattern associated with cultivation surfaces (see Beardsley 1996). Also, LIIIa appears to have been undergoing pedogenic alteration with LIV, though it also exhibits vegetative components of LIV - the dominance of ferns, and LIII - the higher charcoal concentrations, pollen sums, and Polygonum. As such, a tentative conclusion is that mixing through gardening activities eventually created LIIIa. The 'classic' savanna vegetation pattern that dominates LIII to LI may be a later development, as these layers most likely formed by the wash of sediments through erosional activities. If cultivation did occur, it is still not clear whether it was immediately after terrace construction, or later.

As the upper layers all possess higher pollen sums and higher charcoal counts, it is possible this is time-related. The implication here is that the age of the soil surfaces (in this context) correlates with pollen preservation (the younger the surface, the higher the amount of pollen (and charcoal) preserved). This certainly appears to be the case when one reviews the pollen sums (Tables 2, 5, 7) in the uppermost layers at the three sites tested in this project. Therefore, it is proposed that the upper layers of the TR4 were deposited in the late traditional or historic periods. Whether the possible 'cultivation' activity is from the later period or earlier is still uncertain.

The lower layers of the Rois terrace are certainly the result of older terrace-forming and cultural activities. The results imply that the landscape before deposition of the fill layer (LV) was quite stable, with 'classic' savanna vegetation reflected in LVI, supported by a low concentration of charcoal. A transformation occurred once LV was placed to form the terrace, as ferns and allies overshadow the record, and the charcoal concentration increases. This disturbed vegetation pattern continues into LIV.

As no samples were recovered for radiocarbon dating, a 'top-down' construction sequence is posited, whereby the lowest terraces were constructed after the upper terraces. With burials on the top terraces dated to c. $2000 \mathrm{BP}$ (Liston 1999), and assuming the burials were placed in the top terrace not long after it was built, it appears the Rois terraces are potentially older than both Toi Meduu and Ngemeduu.

All told, the vegetation pattern at all three sites reflects a transformed 'physical' landscape through earth-building activities, but also through the record of both disturbed and classic savanna grasslands, supported by charcoal concentrations. It is clear that primary forest and/ or forest re-growth was not part of the ridgeline landscape immediately before or after the earthworks had been formed. An absence of root-crop taxa also questions the agricultural argument posited to explain earthwork construction. 


\section{The pre-earthwork ridgeline vegetation: A 'humanised landscape'?}

In arguments concerning the impact of humans on island ecosystems, we are seeing a focus now on the 'humanisation of forests' and indeed a consideration of the intense humanisation of many Pacific Island landscapes as a whole. The results of the vegetation analyses in this project, in combination with the palaeoenvironmental investigation by Athens and Ward (1999), allow investigation of just how 'humanised' the ridgeline vegetative landscape was before earthwork construction.

In their analysis of the Ngerchau core (which was located at the rear of Ulimang Village at the base of the ridgeline sampled here), Athens and Ward (2001:169-170) identified three 'pollen zones'. It is in the earliest - Zone A - that they point to the first evidence of landscape disturbance (and in their interpretation, human settlement) based on 'significant numerical changes' in disturbance pollen indicators (grass pollen, Pandanus pollen, fern spores) and charcoal concentrations in the core record. This activity is dated to $4291 \mathrm{cal}$. BP (Athens and Ward 2001:171). However, it is not until later, at 2750-2650 cal. BP, that we see the most consistent (and convincing) evidence for land-clearance activities. In Zone C, Pandanus, sedge and grass pollen peak, consistent with a very high concentration in charcoal particles. The Athens and Ward argument suggests methods of agroforestry, with 'landscape [forest] clearance, transformation to savanna formation and fire maintenance for vegetation control' (Athens and Ward 2001:170).

Wickler (2002:69-70) discusses the agricultural argument (Athens and Ward 1999), in which the first sign of disturbance indicators is proposed to mark swidden agriculture activities (i.e. burning). The decline in indicators from 3000 to $2700 \mathrm{cal}$. BP is seen to represent a shift from extensive to intensive agriculture, the intensification seen through terrace construction. The later 'surge' in indicators $(2750-2650 \mathrm{cal}$. BP) is speculated to represent general expansion of agriculture spurred by population growth. So how does this compare to the archaeological remains here?

Firstly, the earliest dates for earthwork construction in the ridgeline are from Rois, at c. 2000 BP. Thus, there is no evidence at this point to suggest earthwork construction around $3000 \mathrm{BP}$, as proposed by IARII. However, there is evidence in the Uplands for occupation from 2500 BP (Liston 1999; Liston and Tuggle 2001), and structural remains were identified during excavation of Ngemeduu dating to c. 2200 BP (Phear 2007). Therefore, the savanna transformation argued by Athens and Ward from 2750-2650 cal. BP has some consistency with cultural activities in the Uplands, and may mark initial movement of people into this topographic zone. The claim that population pressure drove an 'expansion' of agriculture must remain conjectural at this stage, as there is an absence of supporting archaeological evidence. It certainly seems people were using fire to burn vegetation at this time, and it seems a reasonable proposition that they were doing this to clear the land. But why were they clearing the land?

Vegetation clearance in Pacific Island landscapes is generally argued to represent swidden agriculture, or what Zan and Hunter-Anderson (1987:19) call the 'hortigenetic hypothesis'. However, the creation of savanna grasslands is also related to other purposes, such as the creation of paths for movement through the landscape (Zan and Hunter-Anderson 1987), and the clearance of forest to create settlement locales, which are not related to agricultural pursuits. Furthermore, in this study, non-economic motivations are apparent for Upland settlement through interpretations of the cultural remains recovered (Phear 2007), and, as previously stated, no evidence for agricultural crops was recovered in this project. Thus, I argue here that there is no clear correlation between land clearance and cultivation activities in the ridgeline. 
While the vegetation pattern from Rois intimates stable 'classic' savanna before terrace construction, the hilltop sites of Ngemeduu and Toi Meduu reflect a more disturbed grassland environment. My interpretation is that the vegetation in the ridge-top sites was less stable than in the Rois terraces, because the latter vegetation pattern is older. Whether the savanna was created by much earlier clearance activities, or was a natural component of the landscape, is still a matter of debate. Although Zan and Hunter-Anderson (1987) have argued for the presence of 'natural' savannas in Micronesia, recent palaeoenvironmental investigations in Guam provide evidence to the contrary. Athens and Ward declare ' $[\mathrm{t}]$ he finding that humans are responsible for the creation of the savannas that presently extend over broad areas of the interior uplands of southern Guam appears indisputable', therefore dismissing any claims for 'natural' savanna growth. However, further work addressing the Palauan palaeoenvironment is required before the possibility of naturally occurring savannas is dismissed. For Toi Meduu and Ngemeduu, at least, it appears the landscape was cleared during, or just before, upland occupation, and thus the savanna here is anthropogenically created.

To conclude, this small project endeavoured to assess evidence for agriculture in the earthworks, and to look for direct and indirect evidence of landscape vegetative transformations. The excavation and analytical analyses have shown firstly that there is no evidence to suggest the earthworks were constructed for agricultural production. While there is some evidence of cultivation on the Rois terrace, this may have taken place long after the terrace was completed. There are problems concerning the survival of certain types of pollen and phytoliths (that would clearly indicate cultivation) in the archaeological record, and these problems have been discussed elsewhere. While such issues in preservation are acknowledged, when the evidence and results (environmental and archaeological) for this project are considered together, an argument for terrace construction within an intensified agricultural system is not supported. The results expounded here are but one facet of an investigation into the monumental earthworks of Ngaraard. When considered in concert with additional analytical evidence derived from clay and pottery analyses, along with previous earthwork studies, a detailed picture of landscape transformation is formed, one that does not support a subsistence-based argument for monumental earthwork construction (see Phear 2007). The results of this study are by no means exhaustive, and further investigations of earthworks are necessary throughout Babeldaob, looking at pollen and phytolith remains, to form a more detailed picture of landscape transformation for this volcanic island.

\section{Acknowledgements}

The earthwork project was undertaken as $\mathrm{PhD}$ research, with Atholl Anderson as my supervisor. It developed out of the Palau 2000 Project where I first saw the earthworks, and to which Atholl provided support for my initial project plan. I am forever grateful for Atholl's support and wisdom, and his sense of humour in the field and office, which made the $\mathrm{PhD}$ process more bearable! The project would not have happened without funding from the Department of Archaeology and Natural History, ANU, along with funding from the Centre for Archaeological Research, ANU. I am grateful to Vicki Kanai (Director, Bureau of Arts and Culture) and Rita Olsudong (Head of Archaeology, Ministry of Community and Cultural Affairs) for approving my project, and providing me access to the BAC GIS database. I also thank the Governor of Ngaraard for his willingness for my project to go ahead. I thank the field team in Ngaraard: Meked, Jenny, Mathius, Rocky and John, and also Vince Blaiyok for his guidance. I express 
thanks to IARII, which helped the project come to fruition, particularly Jolie Liston for her endless support and discussions concerning the terraces. Support and guidance also came from staff and students in the Department of Archaeology and Natural History, ANU, to whom I am grateful. I also thank Geoff Hope, Mike Macphail, Simon Haberle and Janelle Stevenson for their help and discussions concerning the analytical methods used in this project as well as vegetation interpretations, and also Domique O'Dea and Gillian Atkin for sample processing, and Jeff Parr for the phytolith analysis. My thanks also go to Paul Rainbird and Hal Dalwood for commenting on an earlier draft.

\section{References}

Anderson, A., J. Chappell, G. Clark and S. Phear 2005. Comparative radiocarbon dating of lignite, pottery and charcoal samples from Babeldaob Island, Republic of Palau. Radiocarbon 47:1-9.

Athens, J.S. and J.V. Ward 1999. Archaeological Data Recovery for the Compact Road, Babeldaob Island, Republic of Palau: Historic Preservation Investigations Phase II, Volume IV: The Holocene Palaeoenvironment of Palau. International Archaeological Research Institute Inc. (Draft).

Athens, J.S. and J.V. Ward. 2001. Palaeoenvironmental evidence for early human settlement in Palau: The Ngerchau core. In C.M. Stevenson, G. Lee, and F.J. Morin (eds), Pacific 2000. Proceedings of the Fifth International Conference on Easter Island and the Pacific, pp. 164-177. Los Osos: Bearsville Press.

Athens, J.S. and J.V. Ward 2004. Holocene vegetation, savanna origins and human settlement of Guam. Records of the Australian Museum, Supplement 29:15-30.

Bryant, V.M.J. and J.P. Dering 1996. A guide to paleoethnobotany. Texas: Texas A and M University. Cheyne, A. 1864. Log of the Acis. Held by Sir Joseph Cheyne, Rome.

Clark, R.L. 1982. Point Count Estimation of Charcoal in Pollen Preparations and Thin Sections of Sediments. Pollen et Spores 24:523-535.

Clark, G. 2005. A 3000-Year Cultural Sequence from Palau, Western Micronesia. Asian Perspectives 44(2):349-380.

Clarke, W.C. and R.R. Thaman (eds) 1993. Agroforestry in the Pacific Islands: Systems for Sustainability. Tokyo: The United Nations University Press.

Corwin, C.G., C.L. Rogers and P.O. Elmquist. 1956. Military Geology of the Palau Islands. Intelligence Division, Office of the Engineer, Headquarters US Army Far East.

Easton, W.H. and T.L. Ku. 1980. Holocene sea level changes in Palau, west Caroline Islands. Quaternary Research 14:199-209.

Fitzpatrick, S.M., W.R. Dickinson and G. Clark. 2003. Ceramic petrography and cultural interaction in Palau, Micronesia. Journal of Archaeological Science 30:1175-1184.

Green, R. 1991. Near and Remote Oceania: disestablishing 'Melanesia' in culture history. In J. Davidson, G. Irwin, B.F. Leach, A. Pawley and D. Brown (eds), Oceanic Culture History Essays in Honour of Roger C. Green, pp. 491-502. New Zealand Journal of Archaeology Special Publication. Dunedin: New Zealand Journal of Archaeology.

Haberle, S.G. 1995. Identification of cultivated Pandanus and Colocasia pollen records and the implications for the study of early agriculture in New Guinea. Vegetation History and Archaeobotany 4:195-210.

Henry, J.D., A.E. Haun and M.A. Kirkendall 1996. Archaeological mitigation program: Palau Rural Water System Projects in Chol and Ngkeklau Villages. Paul H. Rosendahl, PhD., Inc.

Horrocks, M., M.D. Jones, J.A. Carter and D.G. Sutton 2000. Pollen and phytoliths in stone mounds at Pouerua, Northland, New Zealand: implications for the study of Polynesian farming. Antiquity 74:863-872. 
Kayanne, H., H. Yamano and R.H. Randall 2002. Holocene Sea-level Changes and Barrier Reef

Formation on an Oceanic Island, Palau Islands, Western Pacific. Sedimentary Geology 150:47-60.

Kealhofer, L. and D.R. Piperno 1998. Opal Phytoliths in Southeast Asian Flora. Smithsonian Contributions to Botany 88:1-39.

Kennedy, J. and B. Clarke 2004. Cultivated Landscape of the Southwest Pacific. Resource Management in Asia-Pacific Working Paper 50:1-47.

Krämer, A. 1917. Palau I. In G. Thilenius (ed), Ergebnisse der Südsee-Expedition 1908-10. II B III. Hamburg: Friederichsen and Co.

Liston, J. 1999. Archaeological Data Recovery for the Compact Road, Babeldaob Island, Republic of Palau: Historic Preservation Investigations Phase II, Volume V: Lab Analyses, Synthesis, and Recommendations. International Archaeological Research Institute Inc., Draft.

Liston, J and D. Tuggle 2001. Warfare in Palau. Paper presented to the Society for American Archaeology 2001 Annual Meeting: The Archaeology of Pre-State and Early State Warfare, New Orleans, Louisiana.

Lucking, L.J. 1984. An Archaeological investigation of prehistoric Palauan terraces. Unpublished PhD thesis, University of Minnesota.

Masse, W.B., D. Snyder and G. Gumerman 1984. Prehistoric and historic settlement in the Palau Islands, Micronesia. New Zealand Journal of Archaeology 6:107-127.

Masse, W.B. and D. Snyder 1982. The Final Report of the 1981 Field Season of the Southern Illinois University Palau Archaeological Project. Historic Preservation Office On file.

Merlin, M. and T. Keene 1990. Dellomel er a Belau: Plants of the Palauan Islands. Honolulu: Environment and Policy Institute, East-West Center.

Morrison, K.D. 1994. The intensification of production: Archaeological approaches. Journal of Archaeological Method and Theory 1:111-159.

Mueller-Dombois, D. and F.R. Fosberg 1998. Vegetation of the tropical Pacific Islands. Ecological Studies: Analysis and Synthesis 132. New York: Springer-Verlag.

Olsudong, R., C.T. Emesiochel and R.T. Kloulechad 2000. Inventory of Cultural and Historical Site and Oral History in Ngaraard State. Volume I: Inventory of Cultural Historical Sites. Division of Cultural Affairs, Historic Preservation Office, Ministry of Community and Cultural Affairs.

Osborne, D. 1966. The Archaeology of the Palau Islands: An intensive survey. Honolulu: Bishop Museum Press.

Osborne, D. 1979. Archaeological test excavations. Palau Islands 1968-69. Micronesica Supplement, 1.

Parmentier, R.J. 1987. The Sacred Remains: Myth, history and polity in Belau. Chicago: University of Chicago Press.

Pearsall, D.M. 1990. Application of phytolith analysis to reconstruction of past environments and subsistence: Recent research in the Pacific. Micronesica Supplement 1:65-74.

Pearsall, D.M. and M.K. Trimble 1984. Identifying past agricultural activity through soil phytolith analysis: A case study from the Hawaiian Islands. Journal of Archaeological Science 11:119-133.

Phear, S., G. Clark and A. Anderson 2003. A 14C Chronology for Palau. In C. Sand (eds), Pacific Archaeology: Assessments and Prospects. Proceedings of the International Conference for the 50 th Anniversary of the first Lapita Excavation, Koné-Nouméa, pp. 255-263. Les Cahiers de l'Archeologie en Nouvelle-Caledonie 15, Noumea: Museum of New Caledonia.

Phear, S. 2007. The Monumental Earthworks of Palau, Micronesia: A landscape perspective. BAR International Series 1626.

Parry, J. 1984. Air Photo Interpretation of Fortified Sites: Ring-Ditch Fortifications in Southern Viti Levu, Fiji. New Zealand Journal of Archaeology 6:71-93.

Rainbird, P. 1994. Prehistory in the Northwest Tropical Pacific: The Caroline, Mariana, and Marshall Islands. Journal of World Prehistory 8:293-349.

Rainbird, P. 2004. The Archaeology of Micronesia. Cambridge World Archaeology. Cambridge: Cambridge University Press. 
Runge, F. 1996. Leaf phytoliths and silica skeletons from east African plants. CD-Rom Database. Germany, Department of Physical Geography, University of Paderborn.

Snyder, D. and B.M. Butler. 1997. Palau Archaeology: Archaeology and Historic Preservation in Palau. Micronesian Resources Study, Anthropology Research Series 2. San Francisco: Micronesian Endowment for Historic Preservation Republic of Palau, U.S. National Park Service.

Stroermer, E.F. and J.P. Smol (eds) 1999. The Diatoms: Applications for the Environmental and Earth Sciences. Cambridge: Cambridge University Press.

UNEP/IUCN. 1988. Coral Reefs of the World. Central and Western Pacific. UNEP Regional Seas Directories and Bibliographies.

Welch, D.J. 2001. Early Upland Expansion of Palauan Settlement. In C.M. Stevenson, G. Lee, and F. J. Morin (eds), Pacific 2000. Proceedings of the Fifth International Conference on Easter Island and the Pacific, pp. 179-184. Los Osos: Bearsville Press.

Werner, D. (ed) 1977. The Biology of Diatoms. Oxford: Blackwell Scientific.

Wickler, S. 2001. The colonization of western Micronesia and early settlement of Palau. In C.M.

Stevenson, G. Lee, and F. J. Morin (eds), Pacific 2000. Proceedings of the Fifth International Conference on Easter Island and the Pacific, pp. 85-196. Los Osos: Bearsville Press.

Zan, Y. and R.L. Hunter-Anderson 1987. On the Origins of the Micronesian 'Savannahs': An Anthropological Perspective. Paper presented to the 3rd International Soil Management Workshop on the Management and Utilization of Acid Soils of Oceania, Belau, 2-6 February. 